Check for updates

Cite this: RSC Adv., 2018, 8, 37665

Received 18th June 2018

Accepted 9th October 2018

DOI: $10.1039 / c 8 r a 05227 a$

rsc.li/rsc-advances

\title{
Alteration of vitrified intermediate level nuclear waste in alkaline media: effects of cementitious materials, $\mathrm{pH}$ and temperature
}

\author{
Tomo Suzuki-Muresan, (D) *a A. Abdelouas, ${ }^{a}$ C. Landesman, (D) a A. Ait-Chaou, ${ }^{a}$ \\ Y. El Mendili, ${ }^{a}$ S. Ribet, ${ }^{a}$ K. Perrigaud, ${ }^{a}$ D. Shitara, ${ }^{b}$ C. Martin ${ }^{c}$ and X. Bourbon ${ }^{c}$
}

\begin{abstract}
Alteration experiments involving intermediate level nuclear waste (ILW) glass in contact with hardened cement paste (HCP) were performed to assess its behavior under simulated repository conditions. Batch experiments were conducted at $20^{\circ} \mathrm{C}$ and $50{ }^{\circ} \mathrm{C}$ in several artificial cement pore water (ACW) samples ( $\mathrm{pH}$ from 10 to 13), in the presence of HCP (CEM-I, CEM-V and low $\mathrm{pH}$ ), with a ratio of glass surface to volume of solution of $8000 \mathrm{~m}^{-1}$ and a ratio of mass of HCP to volume of solution of $10 \mathrm{~g} \mathrm{~L}^{-1}$. Glass alteration rates increase up to $\sim 4 \times 10^{-2} \mathrm{~g} \mathrm{~m}^{-2} \mathrm{~d}^{-1}$ with $\mathrm{pH}$ in contact with HCP, notably with CEM-I. This value decreases by 2 orders of magnitude in low $\mathrm{pH}$ cement solution and also for residual alteration rates. The effect of calcium on glass alteration was observed, mainly in $\mathrm{Ca}(\mathrm{OH})_{2}$ saturated solution, with an incubation effect on the release of $\mathrm{Si}$ in solution. Experimental data were successfully modeled with the PhreeqC geochemical code. Glass and HCP samples were characterized via SEM/EDX and microRaman studies. This work showed that vitrified glass exhibits good performance in terms of low alteration rates $\left(\sim 10^{-4} \mathrm{~g} \mathrm{~m}^{-2} \mathrm{~d}^{-1}\right)$, the absence of secondary phases, and the formation of a gel layer at the surface, when in contact with low pH conditions (in the presence or absence of low pH HCP).
\end{abstract}

\section{Introduction}

The nuclear industry, like any industry, generates a variety of wastes, which, according to their radioactivity levels, are categorized, oriented to suitable disposal solutions and treated according to specific procedures. In general, radioactive wastes are packaged in solid forms to reduce and optimize significantly their volume, to ensure the best properties of confinement and manipulation, and to meet the requirements of safety assessments. ${ }^{1}$ Therefore, vitrification is one of the processes largely proven and notably effective in conditioning high level waste (HLW) for several decades. ${ }^{2}$ Highly exothermic HLW glass is characterized by the presence of residues from the reprocessing of spent nuclear fuel, mainly fission products and minor actinides. In France, the alteration of HLW glass and the understanding of its kinetic and long-term behavior have extensively been studied using simulated inactive SON68 glass and R7T7 doped glass under acidic to alkaline $\mathrm{pH}$ conditions (aqueous media), and from $20{ }^{\circ} \mathrm{C}$ to $100{ }^{\circ} \mathrm{C}$ (aqueous media and relative

${ }^{a}$ SUBATECH (IMT Atlantique, CNRS/IN2P3, Université de Nantes), BP 20722, 44307 Nantes cedex 3, France. E-mail: tomo.suzuki@subatech.in2p3.fr; Fax: +3325185 84 52; Tel: +33251858671

${ }^{b}$ Division of Energy and Environmental Systems, Graduate School of Engineering, Hokkaido University, Kita 13 Nishi 8, Kita-ku, Sapporo, Hokkaido 060-8628, Japan ${ }^{c}$ ANDRA, 1/7, rue Jean Monnet, Parc de la Croix-Blanche, 92298 Châtenay-Malabry, France humidity controlled atmospheres), under repository conditions. ${ }^{3-8}$ The glass surface evolution has extensively been studied in aqueous media, for example the mechanism of gel layer formation, in relation to the formation of secondary mineral phases and their stability. The experimental data (dissolution kinetics, alteration products) has been successfully modeled using geochemical codes..$^{9-14}$ A general multi-step mechanism for aqueous glass alteration has been proposed and validated for a large number of glass types: first hydration, then the interdiffusion of protons and alkali and alkali earth ions, and finally the hydrolysis/recondensation of the glass network. A porous-hydrated-gel layer is therefore formed at the surface leading to a drop in alteration rates (residual alteration rate: $\sim 10^{-4} \mathrm{~g} \mathrm{~m}^{-2} \mathrm{~d}^{-1} ; 90{ }^{\circ} \mathrm{C}$, deionized water) and acting as a diffusion barrier. ${ }^{3}$ Secondary alumino-silicate crystalline phases, such as phyllosilicates, precipitate at the glass surface. ${ }^{13-17}$ However, recent studies by Geisler et $a .^{18}$ and Hellmann et al. ${ }^{19}$ have provided another interpretation of glass dissolution. Indeed, it was shown that under some experimental conditions, the gel layer is formed by a dissolution/ precipitation mechanism, without evidence at micrometer/ nanometer space resolution of interdiffusion-controlled ionexchange during the glass/gel reaction.

The knowledge and understanding acquired regarding HLW glass and the technology developed for making the glass are intended to be transposed to intermediate level waste (ILW). During the decontamination of process equipment following 
the decommissioning and dismantling of the UP2-400 plant at the reprocessing plant at La Hague in France, liquid wastes will be generated for example: $\mathbf{1}^{\mathbf{1 , 2 0 - 2 4}}$ washing reagents $(\mathrm{NaOH}$ and $\mathrm{HNO}_{3}$ ); oxides in rinsing effluents, including transition and platinoid elements ( $\mathrm{Fe}, \mathrm{Cr}, \mathrm{Mn}, \mathrm{Tc}, \mathrm{Ru}, \mathrm{Rh}$ and $\mathrm{Pd}$ ); rare earth and actinide elements (Ce, Gd, U, Pu, Np, Cm and $\mathrm{Am}$ ); main short life $\beta \gamma$-emitters $\left({ }^{137} \mathrm{Cs},{ }^{137 m} \mathrm{Ba},{ }^{90} \mathrm{Sr},{ }^{90} \mathrm{Y},{ }^{241} \mathrm{Pu},{ }^{60} \mathrm{Co}\right)$; main long life $\beta \gamma$-emitters ( ${ }^{63} \mathrm{Ni}$ ); and other elements (Mo, P, S, Ba). Some rinsing effluent wastes from the UP2-800 and UP3 plants of La Hague will also be incorporated. These effluents will be calcined, vitrified by mixing with a glass frit and heated by direct induction in a cold crucible. ${ }^{\mathbf{1} 21}$ The specific requirement of this glass is the incorporation of a higher amount of sodium coming from the waste to be vitrified, which is a limiting factor for the chemical composition and formulation of the glass. ${ }^{\mathbf{1 , 2 4}}$ The glass will be poured into a stainless steel container of the same dimension as that used for HLW. ${ }^{23,24}$ The estimated total activity in the glass will represent less than $1 \%$ of the total volume activity compared to HLW and therefore this glass will be classified as ILW glass..$^{22,23,25}$

Similar to vitrified HLW, ILW glass is planned to be placed in a deep geological formation. However, the ILW glass is expected to be conditioned in a cementitious over-pack imposing high alkaline conditions during the water resaturation period. An evaluation of glass alteration under repository conditions has already been performed in contact with deionized water in unsaturated conditions, but alteration studies in cementitious media are scarce. ${ }^{26-28}$ Countries such as Belgium, the United Kingdom and France are currently involved in such studies. ${ }^{29-31}$ In Belgium, an engineering barrier system concept is designed to place vitrified HLW in a super-container constituted of a carbon steel over-pack surrounded by a Portland cement concrete buffer, with the overall setup enveloped by an outer stainless-steel liner. The key point is to induce the corrosion of the over-pack in a highly alkaline environment and to form corrosion products, which will act as a sink for the retention of radionuclides. ${ }^{29,32}$ In the United Kingdom, alteration studies on ILW glass compositions have been performed in saturated $\mathrm{Ca}(\mathrm{OH})_{2}$ solutions simulating a calcium-rich cementbased environment. ${ }^{30}$ The results showed that calcium may contribute to the formation of a protective gel layer. In France, similar results were obtained by Mercado-Depierre et al. who identified different mechanisms depending on parameters such as $\mathrm{pH}$, the solid to volume ratio $(\mathrm{S} / \mathrm{V})$ and the calcium concentration, ${ }^{28}$ which controls the calcium complexation at the glass surface, the precipitation of calcium silicate hydrate phases $(\mathrm{C}-\mathrm{S}-\mathrm{H})$ or calcium incorporation into the altered layer. Chave et al. showed that whether calcium comes from the glass or the solution, it influences the alteration of nuclear glass and is retained within the silica network in the hydrated layer at the glass surface. ${ }^{33}$ The presence of calcium and the influence of its concentration in solution determine and control the aggregation and gelation processes. On one hand, solutions with high calcium concentrations yield to gels composed of small fractal aggregates and large particles formed just after the addition of calcium. On the other hand, solutions with a low calcium content induce the formation of gels mainly composed of large fractal aggregates coexisting with small primary silicate species. The consequence is an enhancement of the passivating properties of the surface layer. Conversely, according to Jollivet et $a .^{34}$ and Stockmann et al., ${ }^{35}$ calcium has no significant influence on the dissolution rates of nuclear glass. Calcium precipitates with carbonate to form a calcite phase independently of the glass surface. The lack of a structural match between glass and calcium carbonate favors $\mathrm{CaCO}_{3}$ nucleation and growth in the form of discrete crystals. ${ }^{34}$

This paper aims to provide new contributions to the understanding of ILW glass alteration in contact with hardened cement paste (HCP) under simulated disposal conditions. Ordinary Portland Cement (OPC) CEM-I and CEM-V ${ }^{36}$ examples have been used and are compared to a ternary formulated low hydration heat/low-pH HCP. This last cementitious material is formulated with a blend of hydraulic and pozzolanic materials (blast furnace slag, fly ash, and silica fume mixed with CEM I), leading to hydrated cement without portlandite (due to the pozzolanic reaction) and $\mathrm{C}-\mathrm{S}-\mathrm{H}$ with a low $\mathrm{Ca} / \mathrm{Si}(\mathrm{C} / \mathrm{S})$ ratio incorporating small amounts of $\mathrm{Al}^{36,37}$ The hydration of this latter cementitious material generates a low $\mathrm{pH}$ pore water solution ( $\mathrm{pH} \leq 11)$ compared to those involving OPC (13.2-13.5 (ref. 37-41)). This raises the question of their potential application relating to the disposal of ILW glass. The process of pore water chemistry evolution shows that pore water of $\mathrm{pH} \leq 11$ can be achieved via strong reduction under alkali concentrations, and the absence of portlandite when hydration is completed. Under these conditions, the $\mathrm{pH}$ is controlled by the dissolution of $\mathrm{C}-\mathrm{S}-\mathrm{H}$ phases: the lower the $\mathrm{C} / \mathrm{S}$ ratio, the lower the $\mathrm{pH}$.

Studies of the effects of low-pH cements on clay have been performed by Dauzères et al., comparing the physico-chemical behavior of a low-pH material with CEM-I cement paste. ${ }^{\mathbf{4 2}}$ Under aqueous alteration, low-pH HCP was strongly degraded, which results in coarser porosity, whereas the thickness degradation of CEM-I HCP was limited by the precipitation of a magnesium-calcite-silicate crust over the surface, which reduces the exchange of soluble species. Ettringite precipitation occurred, resulting from the dissolution of portlandite in CEM-I HCP, while it dissolved initially in low-pH cements. These authors and Jenni et al. ${ }^{43}$ indicated that mainly leaching and carbonation occurred for low-pH HCP in contact with a clayey environment. Leaching leads to the partial or total decalcification of $\mathrm{C}-\mathrm{S}-\mathrm{H}$ to amorphous silica, resulting in a decrease in strength and the formation of macroporosity. ${ }^{42,43}$ Carbonation is linked to the precipitation of calcite and thus the decalcification of $\mathrm{C}-\mathrm{S}-\mathrm{H}$. Dauzères et al. investigated magnesium perturbation on low-pH cements placed in a clayey environment. ${ }^{44}$ Magnesium perturbation was observed in any kind of environment containing at least $3 \times 10^{-3} \mathrm{~mol} \mathrm{~L}^{-1}$ of magnesium in the pore solution, and produced a mineralogical phase identified as magnesium-silicate-hydrate (M-S-H).

There is no literature about the effects of low-pH cement on glass alteration, while the effects of OPC have been presented by many authors. For example, Ferrand et al. conducted glass leach tests at $30{ }^{\circ} \mathrm{C}$ in suspensions of OPC. ${ }^{45}$ The authors showed that the cement appeared to trigger glass dissolution via the consumption of glass matrix components, leading to fast glass dissolution at a constant rate with the formation of a porous gel layer on the glass. The two main reactions are: (1) the reaction of 
Table 1 The composition of simulated French nuclear waste glass for intermediate level waste (ILW)

\begin{tabular}{|c|c|}
\hline Oxide & ILW glass ${ }^{27}$ weight $\%$ \\
\hline $\mathrm{SiO}_{2}$ & 50.33 \\
\hline $\mathrm{B}_{2} \mathrm{O}_{3}$ & 14.44 \\
\hline $\mathrm{Na}_{2} \mathrm{O}$ & 12.58 \\
\hline $\mathrm{Al}_{2} \mathrm{O}_{3}$ & 8.7 \\
\hline $\mathrm{CaO}$ & 3.1 \\
\hline $\mathrm{Li}_{2} \mathrm{O}$ & 2.17 \\
\hline $\mathrm{Fe}_{2} \mathrm{O}_{3}$ & 2.84 \\
\hline $\mathrm{NiO}$ & 0.33 \\
\hline $\mathrm{Cr}_{2} \mathrm{O}_{3}$ & 0.07 \\
\hline $\mathrm{SO}_{3}$ & 0.19 \\
\hline $\mathrm{P}_{2} \mathrm{O}_{5}$ & 0.42 \\
\hline \multicolumn{2}{|l|}{$\mathrm{ZnO}$} \\
\hline $\mathrm{ZrO}_{2}$ & 1.99 \\
\hline $\mathrm{MoO}_{3}$ & 0.69 \\
\hline $\mathrm{MnO}_{2}$ & 0.19 \\
\hline $\mathrm{CoO}$ & 0.27 \\
\hline $\mathrm{BaO}$ & 0.36 \\
\hline \multicolumn{2}{|l|}{$\mathrm{La}_{2} \mathrm{O}_{3}$} \\
\hline \multicolumn{2}{|l|}{$\mathrm{Ce}_{2} \mathrm{O}_{3}$} \\
\hline \multicolumn{2}{|l|}{$\mathrm{Nd}_{2} \mathrm{O}_{3}$} \\
\hline $\mathrm{RuO}_{2}$ & 0.12 \\
\hline Oxides (fission products + actinides) & 0.47 \\
\hline Other & 0.74 \\
\hline Total & 100 \\
\hline
\end{tabular}

Si released by glass with portlandite, forming $\mathrm{C}-\mathrm{S}-\mathrm{H}$; and (2) the reaction of $\mathrm{Al}$ released by glass with $\mathrm{C}-\mathrm{S}-\mathrm{H}$, forming $\mathrm{C}-\mathrm{A}-\mathrm{S}-\mathrm{H}$ phases. The key mechanism driving the long-term glass dissolution is the formation of secondary phases. After the consumption of portlandite, the glass alteration rate is expected to decrease. Therefore, the present research aims to provide new findings about the effects of low-pH cement on glass dissolution.

\section{Experimental setup and methodology}

\subsection{Alteration experiments on glass and hardened cement pastes}

\subsubsection{Solid samples}

2.1.1.1. Glass. French nuclear glass simulating intermediate level waste (ILW glass) was synthesized by CEA in the form of a rectangular block, whose composition is given in Table 1. ILW glass is an inactive surrogate glass, constituted of network formers ( $\mathrm{Si}, \mathrm{B}$, and $\mathrm{Al}$ ), network modifiers ( $\mathrm{Na}, \mathrm{Ca}$, and $\mathrm{Li}$ ) and intermediate metals ( $\mathrm{Zr}, \mathrm{Al}$, and $\mathrm{Zn}$ ). The particular feature of this type of glass is its $\mathrm{Si}, \mathrm{Al}$ and $\mathrm{Na}$ oxide enrichment, and the depletion of oxides simulating fission products $\left(\mathrm{TeO}_{2}, \mathrm{Cs}_{2} \mathrm{O}\right.$, $\left.\mathrm{MnO}_{2}, \mathrm{La}_{2} \mathrm{O}_{3}\right)$ and minor actinide oxides $\left(\mathrm{Nd}_{2} \mathrm{O}_{3}, \mathrm{Ce}_{2} \mathrm{O}_{3}\right)$.

Two types of glass were used: glass powder and glass monolith plates. Glass monoliths were sent to the PRIMEVERRE Company to be prepared as a powder with a controlled grain size (between 50 and $100 \mu \mathrm{m}$ ). Finally, the glass powder was cleaned in ethanol via ultrasound and dried at $90{ }^{\circ} \mathrm{C}$. The specific surface area was measured by BET methods using Krgas $\left(688 \mathrm{~cm}^{2} \mathrm{~g}^{-1}\right)$. The powder was used in batch alteration experiments.

Thin glass monoliths, with dimensions of $25 \mathrm{~mm} \times 25 \mathrm{~mm}$ $\times 1 \mathrm{~mm}$, were cut from the block glass, polished to $3 \mu \mathrm{m}$ and cleaned with ethanol. These samples were specifically prepared for solid characterization after long-term alteration.

2.1.1.2. Hardened cement pastes. Three hardened cement pastes (HCPs) were provided by LMDC (Laboratoire Matériaux et Durabilité des Constructions, INSA-Toulouse, France): (1) ordinary Portland Cement (CEM I, Val d'Azergue, Lafarge, France) cured over 34 months with a water to cement ratio (w/c) of 0.43 ; (2) blast furnace slag/fly ash cement (CEM V, Airvault, Calcia, France) cured over 35 months $(w / c=0.43)$; and (3) low$\mathrm{pH}$ HCP, a ternary mixture of OPC $(37.5 \% \mathrm{w} / \mathrm{w})$, silica fume $(32.5 \% \mathrm{w} / \mathrm{w})$ and fly ash $(30 \% \mathrm{w} / \mathrm{w})$, cured over 33 months $(\mathrm{w} / \mathrm{c}=$ 0.50). CEM-I and CEM-V are two HCPs considered by the French radioactive waste management agency (Andra) in their longterm behavior surveys. They are used in this work as reference materials to compare their performances to that of low-pH HCP. The HCPs were crushed manually in an agate mortar and sieved between 100 and $160 \mu \mathrm{m}$. All solid preparations were performed in a glove box under inert gas (argon) to avoid any contamination by atmospheric $\mathrm{CO}_{2}(\mathrm{~g})$ gas, which is deleterious for HCP (the precipitation of calcite).

2.1.2. Solution composition. Three artificial cement pore water (ACW) samples were prepared by dissolving salts in decarbonated (under vacuum), de-aerated, ultra-pure water (MilliQ, 18.2 Mohm $\mathrm{cm}^{-1}$ ) in a glove box filled with argon. Their compositions are given in Table 2 . Solution $\mathrm{S} 1 \mathrm{~b}$, named young

Table 2 The chemical composition of artificial cement pore water synthesized from ANDRA ${ }^{24}$

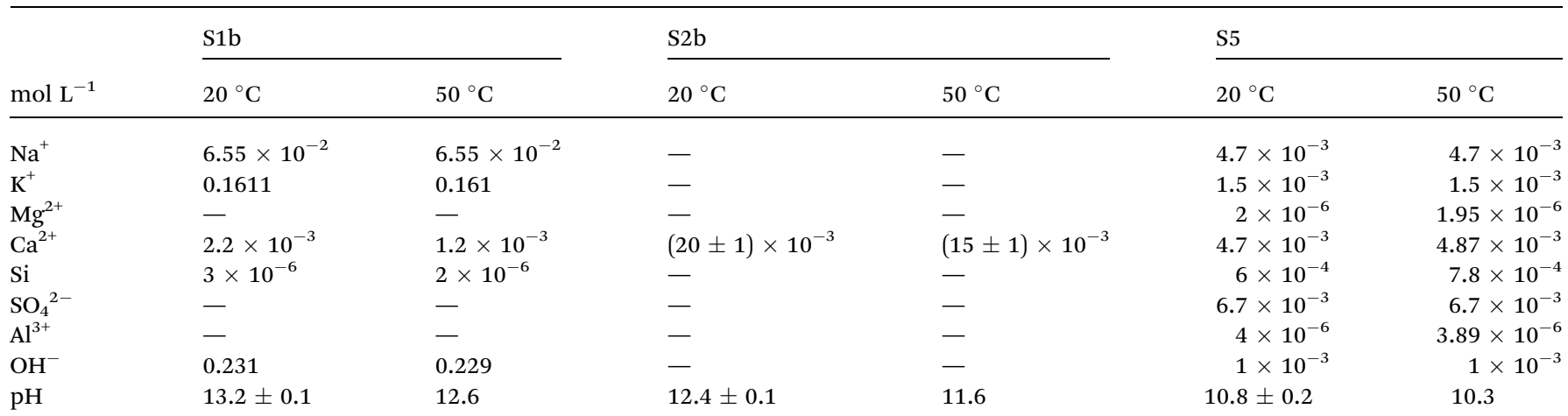


cement water (YCW), gives the highest alkaline $\mathrm{pH}$ value, representing the degradation of CEM-I and CEM-V type HCP $(\mathrm{pH}$ 13.2 at $20{ }^{\circ} \mathrm{C}$ and 12.6 at $50{ }^{\circ} \mathrm{C}$ (ref. 24)). The composition of this solution has been simplified from a pore water solution of CEMI HCP: only the main species ( $\mathrm{Na}, \mathrm{K}$, and $\mathrm{Ca}$ ) are then considered. Solution S2b corresponds to a solution in equilibrium with portlandite, which corresponds to hydrated cement showing alkaline ion depletion. The $\mathrm{pH}$ of this solution, commonly named $\mathrm{Ca}(\mathrm{OH})_{2}$ solution, is buffered at 12.4 by portlandite at $25{ }^{\circ} \mathrm{C}$. Solution S5, also named 'low-pH', corresponds to a solution in equilibrium with low $\mathrm{C} / \mathrm{S}$ ratio $\mathrm{C}-\mathrm{S}-\mathrm{H}$ phases $\left(\mathrm{pH} 10.8\right.$ at $20{ }^{\circ} \mathrm{C}$, and 10.3 at $50{ }^{\circ} \mathrm{C}$ (ref. 24 and 46)) to represent the pore water of low-pH hydrated cement.

2.1.3. Batch alteration experiments. Experiments were conducted in Teflon ${ }^{\circledR}$ vials with conditioning in an Ar-gas glove box. Nine types of experiments were conducted, either in binary (glass or $\mathrm{HCP} /$ solution) or ternary (glass/HCP/solution) systems (Table 3):

- Experiment (1): the alteration of glass powder in S1b, S2b or S5 solution $\left(116 \mathrm{~g} \mathrm{~L}^{-1}\right)$;

Table 3 The experimental setup and a summary of the experimental program for binary systems (glass or HCP/solution) and ternary systems (glass/HCP/solution) at $20^{\circ} \mathrm{C}$ and $50^{\circ} \mathrm{C}$

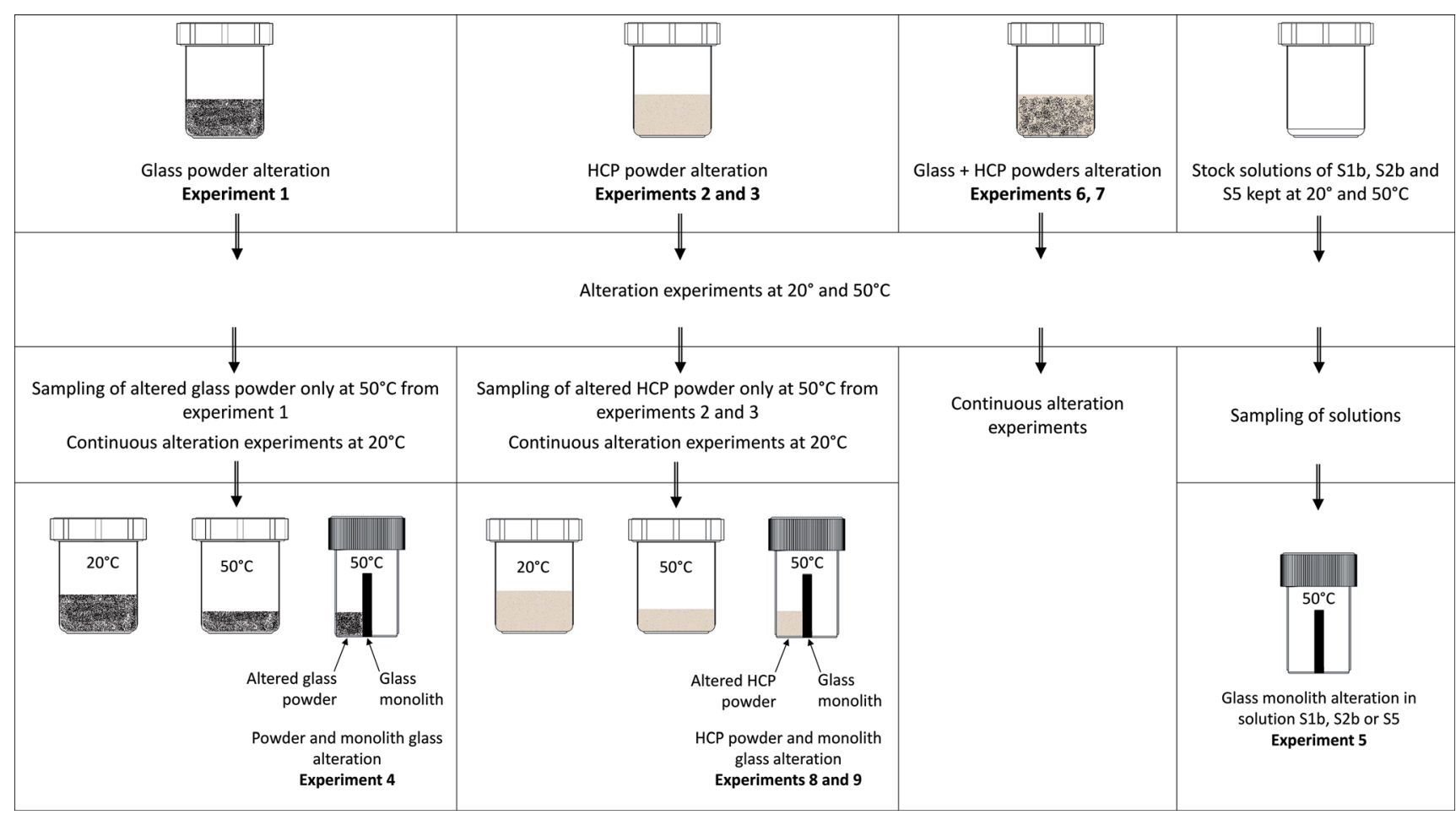

\begin{tabular}{llll} 
& & & Solution \\
\cline { 3 - 4 } Binary system & \multicolumn{1}{c}{ Materials } & S1b & S2b \\
\hline Experiment 1 & Glass powder $\left(20^{\circ} \mathrm{C}, 50^{\circ} \mathrm{C}\right)$ & $x$ & $x$ \\
Experiment 2 & CEM-I, CEM-V powder $\left(20^{\circ} \mathrm{C}, 50^{\circ} \mathrm{C}\right)$ & $x$ & $x$ \\
Experiment 3 & Low-pH powder $\left(20^{\circ} \mathrm{C}, 50^{\circ} \mathrm{C}\right)$ & & $x$ \\
Experiment 4 & Glass monolith $\left(50^{\circ} \mathrm{C}\right)$ & $x$ & $x$ \\
Experiment 5 & Glass powder + glass monolith $\left(50^{\circ} \mathrm{C}\right)$ & $x$ & $x$ \\
\hline
\end{tabular}

\begin{tabular}{|c|c|c|c|c|c|c|}
\hline \multirow[b]{3}{*}{ Ternary system } & \multirow[b]{3}{*}{ Material } & \multicolumn{5}{|c|}{ Solution/HCP } \\
\hline & & \multicolumn{2}{|c|}{$\mathrm{S} 1 \mathrm{~b}$} & \multicolumn{2}{|c|}{$\mathrm{S} 2 \mathrm{~b}$} & \multirow{2}{*}{$\frac{\text { S5 }}{\text { Low-pH }}$} \\
\hline & & CEM-I & CEM-V & CEM-I & CEM-V & \\
\hline Experiment 6 & Glass powder $\left(20^{\circ} \mathrm{C}, 50^{\circ} \mathrm{C}\right)$ & $x$ & $x$ & $x$ & $x$ & \\
\hline Experiment 7 & Glass powder $\left(20^{\circ} \mathrm{C}, 50^{\circ} \mathrm{C}\right)$ & & & & & $x$ \\
\hline Experiment 8 & Glass monolith (only at $50^{\circ} \mathrm{C}$ ) & $x$ & $x$ & $x$ & $x$ & \\
\hline Experiment 9 & Glass monolith (only at $50^{\circ} \mathrm{C}$ ) & & & & & $x$ \\
\hline
\end{tabular}


- Experiment (2): the alteration of CEM-I and CEM-V HCP in S1b or S2b solution $\left(10 \mathrm{~g} \mathrm{~L}^{-1}\right)$;

- Experiment (3): the alteration of low-pH HCP in solution S5 $\left(10 \mathrm{~g} \mathrm{~L}^{-1}\right)$;

- Experiment (4): the alteration of glass powder $\left(90 \mathrm{~g} \mathrm{~L}^{-1}\right)+$ a glass monolith $\left(65 \mathrm{~g} \mathrm{~L}^{-1}\right)$ in S1b, S2b or S5 solution;

- Experiment (5): the alteration of a glass monolith in contact with $\mathrm{S} 1 \mathrm{~b}, \mathrm{~S} 2 \mathrm{~b}$ or $\mathrm{S} 5$ solution $\left(65 \mathrm{~g} \mathrm{~L}^{-1}\right)$;

- Experiment (6): the alteration of glass powder $\left(116 \mathrm{~g} \mathrm{~L}^{-1}\right)$ in contact with CEM-I and CEM-V HCP $\left(10 \mathrm{~g} \mathrm{~L}^{-1}\right)$ in S1b or S2b solution;

- Experiment (7): the alteration of glass powder $\left(116 \mathrm{~g} \mathrm{~L}^{-1}\right)$ in contact with low-pH HCP $\left(10 \mathrm{~g} \mathrm{~L}^{-1}\right)$ in S5 solution;

- Experiment (8): the alteration of a glass monolith $\left(65 \mathrm{~g} \mathrm{~L}^{-1}\right)$ in contact with CEM-I and CEM-V HCP $\left(80 \mathrm{~g} \mathrm{~L}^{-1}\right)$ in S1b or S2b solution;

- Experiment (9): the alteration of a glass monolith $\left(65 \mathrm{~g} \mathrm{~L}^{-1}\right)$ in contact with low-pH HCP $\left(80 \mathrm{~g} \mathrm{~L}^{-1}\right)$ in S5 solution.

Experiments 4, 8 and 9 were conducted in two steps: (1) the first step consisted of the equilibration of glass powder or HCP with the solution (for example: CEM-I HCP in solution S1b, low$\mathrm{pH}$ HCP in solution S5) at $50{ }^{\circ} \mathrm{C}$; and (2) the equilibrated solution was thereafter put in contact with the glass monolith and kept at $50{ }^{\circ} \mathrm{C}$. The monolith separates the vial into two compartments, in which one side (the front side) is in contact with glass powder (experiment 4) or HCP (experiments 8 and 9) and the other side (the rear side) is free of solids. For experiment 5 , both sides of the monolith are in contact with solution only. These specific experiments (Exp. 4, 5, 8 and 9) were dedicated to studying the effects of solids in contact with the glass monolith and to allow surface characterization via EDXSEM and micro-Raman studies. Table 3 presents the general experimental setup. Aliquots were sampled and filtered at 0.45 $\mu \mathrm{m}$ in a glove box for ICP-MS and ion chromatography analyses and $\mathrm{pH}$ measurements. The $\mathrm{pH}$ electrode was calibrated at room temperature using buffer solutions between $\mathrm{pH} 7$ and 12.45 (Radiometer $\mathrm{pH}$ buffer). For all experiments conducted at $50{ }^{\circ} \mathrm{C}$, the solutions were cooled down at room temperature before measurements.

\subsection{Solution analysis and solid characterization}

All solutions were stored in a refrigerator at $4{ }^{\circ} \mathrm{C}$ until analyses were carried out. $\mathrm{Li}, \mathrm{B}, \mathrm{Mo}, \mathrm{Si}$, and $\mathrm{Al}$ concentrations were analyzed via inductively coupled plasma mass spectrometry (Quadrupole ICP-MS Xseries 2, THERMOELECTRON). The limits of quantification (LQS) are $0.3 \mu \mathrm{g} \mathrm{L} \mathrm{L}^{-1}$ for $\mathrm{Li}, 1.3 \mu \mathrm{g} \mathrm{\textrm {L } ^ { - 1 }}$ for $\mathrm{B}, 7.5 \mu \mathrm{g} \mathrm{\textrm {L } ^ { - 1 }}$ for $\mathrm{Si}$, and $0.2 \mu \mathrm{g} \mathrm{L}^{-1}$ for $\mathrm{Al}$, with an analytical uncertainty of $5-10 \%$. Prior to analysis, samples were filtered (Minisart $0.45 \mu \mathrm{m}$ cellulose filters) and diluted in $2 \%$ vol. high purity $\mathrm{HNO}_{3}$ solution.

$\mathrm{Ca}, \mathrm{K}, \mathrm{Na}$, and $\mathrm{SO}_{4}$ concentrations were analyzed via ion chromatography (DIONEX ICS 2500). The LQs are $0.1 \mathrm{mg} \mathrm{L}^{-1}$, with an error of $5 \%$. Prior to analysis, samples were filtered (Millex PTFE $0.45 \mu \mathrm{m}$ filters). The samples are diluted in ultrapure water or in eluent for anion or cation analysis, respectively.
Crystallographic structures were recorded via X-ray diffractometry (BRUKER-AXS D5000, Bragg-Brentano geometry, copper anticathode, $\mathrm{Cu}$, at $\lambda=1.5406 \AA$, room temperature) for pristine and reacted glass powder, as well as for HCPs. Data were collected in the $2 \theta$ range of $5^{\circ}$ to $90^{\circ}$ with a step size of $0.02^{\circ}$ and a scan-speed of $10 \mathrm{~s}$ per step. Phases were identified using the DIFFRAC ${ }^{\text {Plus }}$ EVA software package (BRUKER).

Morphologies and elemental chemical compositions were determined using electron dispersion spectroscopy (EDS) coupled with scanning electron microscopy (SEM, JEOL 5800 $\mathrm{LV}, 15 \mathrm{kV}$ ). Samples were coated by a thin layer of carbon, allowing for the detection of elements $(Z>11)$. Flat glass surfaces and polished cross sections were prepared in epoxyresin (Epofix, Struers) for analysis.

Secondary mineral phases were characterized with a confocal micro-Raman spectrometer (T64000 Jobin-Yvon/ Horiba, room temperature). Raman spectra were recorded under a microscope (Olympus Bx41) in backscattering geometry with a $100 \times$ objective focusing the $647.1 \mathrm{~nm}$ and $514 \mathrm{~nm}$ beam lines from an argon-krypton ion laser (Spectrum Coherent, 2.5 W). The Raman experiments were performed using a spectrometer equipped with a 600 lines per $\mathrm{mm}$ diffraction grating and a nitrogen cooled CCD detector. The spectral resolution is $2 \mathrm{~cm}^{-1}$. The acquisition and basic treatment of spectra were performed with LabSpec V5.25 (Jobin Yvon-Horiba) and Origin 8.6 software. Raman measurements were carried out at a very low laser power to minimize possible sample deterioration or phase transitions during the operating time.

\subsection{Data processing}

The glass elemental normalized mass loss $\left(\mathrm{NL}_{\mathrm{i}}, \mathrm{g} \mathrm{m}^{-2}\right)$ is calculated using the equation:

$$
N L_{\mathrm{i}}=\frac{C_{\mathrm{i}}}{X_{\mathrm{i}} \times(S / V)}
$$

where $C_{\mathrm{i}}$ is the concentration of element $\mathrm{i}$ in solution in $\mathrm{g} \mathrm{m}^{-3}$, $X_{\mathrm{i}}$ is the weight fraction of element $\mathrm{i}$ in pristine glass, $S$ is the surface area $\left(\mathrm{m}^{2}\right)$ of the sample, and $V$ is the volume of solution $\left(\mathrm{m}^{3}\right)$.

The glass alteration rate $\left(\mathrm{NLR}_{\mathrm{i}}, \mathrm{g} \mathrm{m}^{-2} \mathrm{~d}^{-1}\right)$ is then calculated via the following equation:

$$
\mathrm{NLR}_{\mathrm{i}}=\frac{\Delta \mathrm{NL}_{\mathrm{i}}}{\Delta t}
$$

where $\Delta t$ corresponds to an interval in contact time (d), and $\Delta \mathrm{NL}_{\mathrm{i}}$ is the variation of normalized mass loss within this interval.

From the normalized mass loss values, the equivalent altered thickness $\left(\mathrm{EE}_{\mathrm{eq}}, \mu \mathrm{m}\right)$ was determined as follows:

$$
\mathrm{EE}_{\mathrm{eq}}=\frac{\mathrm{NL}_{\mathrm{i}}}{\rho}
$$

where $\rho$ is the density of pristine glass $\left(2.7 \mathrm{~g} \mathrm{~cm}^{-3}\right)$.

\subsection{Modelling}

The experimental data were modelled with the geochemical code PhreeqC (version 2.17) ${ }^{47}$ and the THERMOCHIMIE 
(version 9 (2014)) ${ }^{48}$ database. Modelling calculations were conducted for binary and ternary systems, such as glass powder alone (Exp. 1), glass powder + CEM-I/CEM-V HCP (Exp. 6), and glass powder + low-pH HCP (Exp. 7) at $20^{\circ} \mathrm{C}$ and $50{ }^{\circ} \mathrm{C}$.

The glass composition is defined according to the following molar proportions: $\mathrm{SiO}_{2}=0.551 ; \mathrm{Na}_{2} \mathrm{O}=0.1335 ; \mathrm{B}_{2} \mathrm{O}_{3}=0.136$; $\mathrm{Al}_{2} \mathrm{O}_{3}=0.056 ; \mathrm{CaO}=0.0364 ; \mathrm{Li}_{2} \mathrm{O}=0.0478 ; \mathrm{Fe}_{2} \mathrm{O}_{3}=0.0117$; $\mathrm{MoO}_{3}=0.00315$; and $\mathrm{SO}_{3}=0.0011$. For the cement, the following main phases: portlandite; $\mathrm{C}-\mathrm{S}-\mathrm{H}$; ettringite; and monosulfoaluminate, were considered to dissolve or precipitate instantaneously to reach thermodynamic equilibrium in solution. ${ }^{42}$ The compositions and phase distributions of CEM-I and CEM-V HCP are recalculated from Trotignon et al. ${ }^{49}$ For experiments in contact with HCP, thermodynamic equilibria with portlandite, ettringite, monosulfoaluminate, and different $\mathrm{C}-\mathrm{S}-\mathrm{H}$ values $(\mathrm{Ca} / \mathrm{Si}$ ratios equal to $0.8,1.2$, and 1.6$)$ were considered.

\section{Results and discussion}

\subsection{Solid characterization}

3.1.1. Characterization of HCP. Fig. 1 shows the X-ray diffraction patterns of CEM-I, CEM-V and low-pH HCP before alteration (pristine), with the main phases expected in each hardened cement paste. The results are summarized in Table 4, showing the existing phases in the solid samples: $\mathrm{C}-\mathrm{S}-\mathrm{H}$;

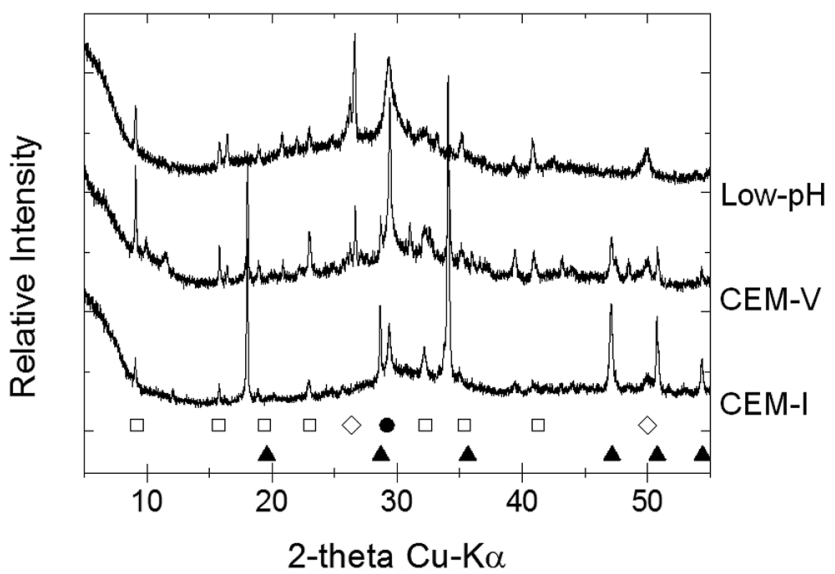

Fig. 1 X-ray diffraction patterns of initial CEM-I, CEM-V and low-pH HCP powder (Exp. 2 and 3): ( $\square$ ) ettringite; $(\bullet)$ calcite; $(\diamond)$ quartz; $(\bullet)$ portlandite.

Table 4 Mineralogy of the different pristine and altered CEM-I, CEM-V and low-pH hydrated cement pastes

\begin{tabular}{|c|c|c|c|c|c|c|}
\hline \multirow[b]{2}{*}{ Phase } & \multicolumn{2}{|c|}{ CEM-I } & \multicolumn{2}{|c|}{ CEM-V } & \multicolumn{2}{|c|}{ Low-pH } \\
\hline & Pristine & Altered & Pristine & Altered & Pristine & Altered \\
\hline Portlandite & $\checkmark$ & $\checkmark$ & & & & \\
\hline Ettringite & $\checkmark$ & & $\checkmark$ & & $\checkmark$ & \\
\hline Calcite & $\checkmark$ & $\checkmark$ & $\checkmark$ & $\checkmark$ & $\checkmark$ & $\checkmark$ \\
\hline Quartz & & & $\checkmark$ & $\checkmark$ & $\checkmark$ & $\checkmark$ \\
\hline C-S-H & $\checkmark$ & $\checkmark$ & $\checkmark$ & $\checkmark$ & $\checkmark$ & $\checkmark$ \\
\hline
\end{tabular}

ettringite; quartz; and calcite, for the cements. In addition, a portlandite phase is also found in CEM-I. These results are in agreement with the standard compositions of hardened cement pastes.

After the alteration stage at $50{ }^{\circ} \mathrm{C}$, water molecules may be released from the structure of ettringite, reducing its crystallinity or converting it into an amorphous structure. ${ }^{50-52}$ Moreover, ettringite becomes more soluble with an increase in $\mathrm{pH}$, notably in solution S1b for CEM-I and CEM-V HCP. ${ }^{53}$ Therefore, the $\mathrm{pH}$ effect is coupled with the temperature effect. Conversely, the dissolution of ettringite in low-pH HCP may not be attributable to $\mathrm{pH}$ change, but to temperature. The destabilization of ettringite can be explained by the fact that the stability range of ettringite diminishes with temperature in favor of the formation of calcium monosulfo-aluminate hydrate. This result is supported in the literature in an example from Damidot et al., who mentioned the range of ettringite stability in terms of $\mathrm{pH}$ range: ${ }^{54} 10.43<\mathrm{pH}<12.52\left(25{ }^{\circ} \mathrm{C}\right) ; 10.52<\mathrm{pH}<12.41\left(50{ }^{\circ} \mathrm{C}\right)$; and $10.87<\mathrm{pH}<12.25\left(85^{\circ} \mathrm{C}\right)$.

3.1.2. Surface characterization of glass. Glass monolith (Exp. 5, Fig. 2, Tables 3 and 5). The surfaces of glass monoliths altered in S1b, S2b and S5 solution at $50{ }^{\circ} \mathrm{C}$ for 380 days, were analyzed via SEM/EDX and micro-Raman studies.

In $\mathrm{S} 1 \mathrm{~b}$ solution, the surface presents a desquamated form, probably due to the combined effects of temperature $\left(50^{\circ} \mathrm{C}\right)$ and high $\mathrm{pH}$ (13.2). Magnification of the surface reveals the presence of a gel that is, from EDX analyses, enriched in calcium relative to the initial glass composition, which could be attributed to Ca diffusion through the gel.

In $\mathrm{S} 2 \mathrm{~b}$ solution, the surface is characterized by the presence of a gel and precipitates. EDX analysis shows that the gel is composed of silicon and calcium with a $\mathrm{Ca} / \mathrm{Si}$ ratio of 1.1; however, micro-Raman analysis indicates a lower ratio, corresponding to a phase close to a tobermorite-like phase. Analyses shows that the precipitates, clustered together, are enriched in calcium and were identified as calcite via micro-Raman analysis.

In S5 solution, the glass has a homogeneous surface with the presence of an alteration gel. Analysis of this surface via microRaman studies indicates the presence of $\mathrm{Si}, \mathrm{Al}, \mathrm{Ca}$ and $\mathrm{Na}$. A phase search seems to indicate the presence of a gyrolite-like phase with a low $\mathrm{Ca} / \mathrm{Si}$ ratio.

Glass powder in contact with a glass monolith (Exp. 4, Tables 3 and 6). Altered glass powder was put into contact with a fresh glass monolith. The binary glass powder/glass monolith system was thereafter altered in S1b, S2b and S5 solution at $50{ }^{\circ} \mathrm{C}$. After 380 days of alteration, the systems were dismantled and the front (presence of glass powder) and rear (absence of glass powder) sides of the glass monolith were analyzed via SEM/EDX and micro-Raman analysis (Fig. 2).

In S1b solution, the area of the monolith surface in contact with glass powder shows the formation of phyllosilicate-like phases, which are commonly formed during borosilicate glass alteration. ${ }^{12,55}$ EDX analysis of the globular precipitates indicates the presence of $\mathrm{Si}, \mathrm{Al}$ and $\mathrm{Ca}$. For a post-mortem characterization of the glass monolith via SEM, the glass powder was separated from the surface of the monolith, showing bright 

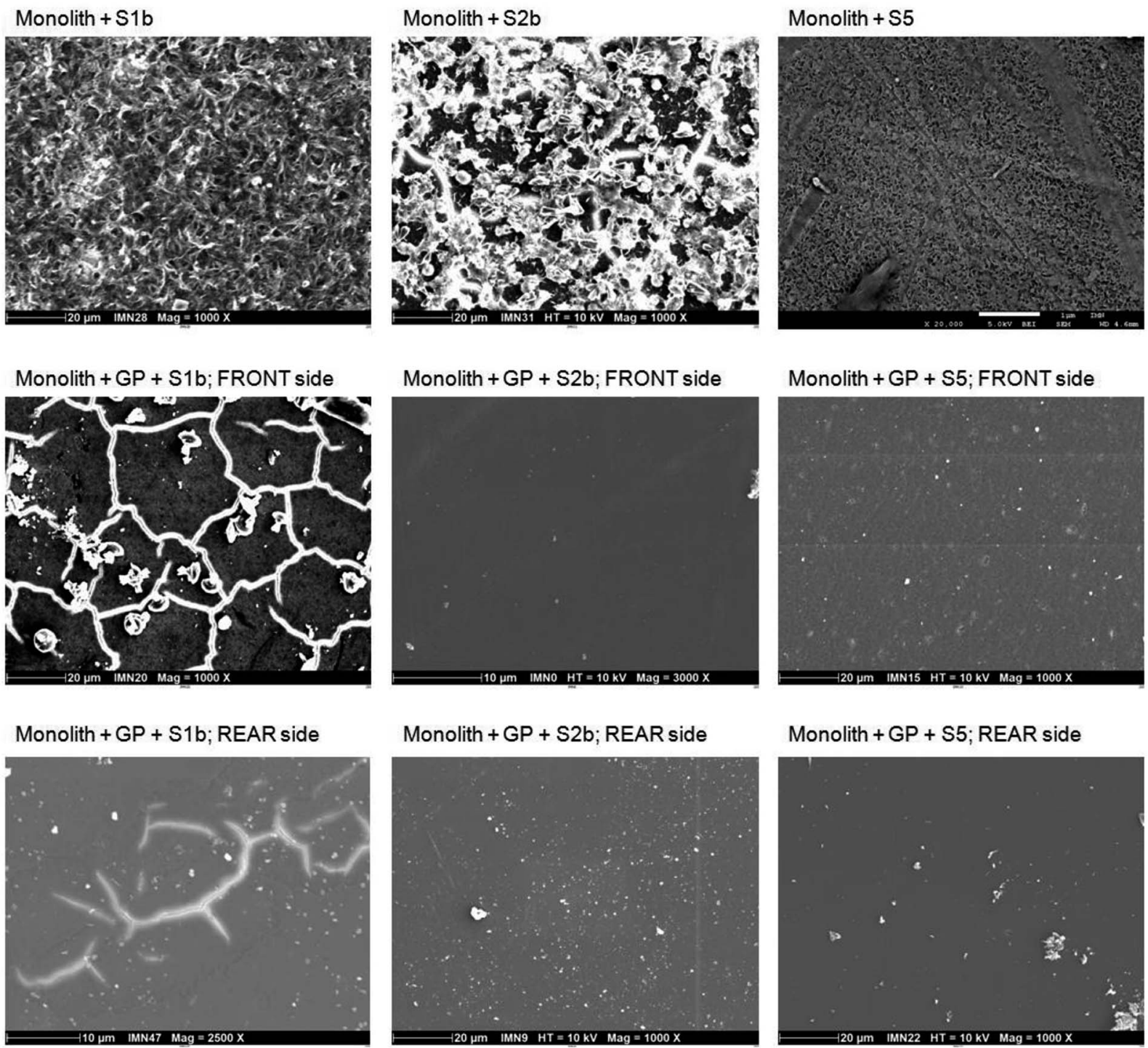

Monolith + GP + S5; REAR side

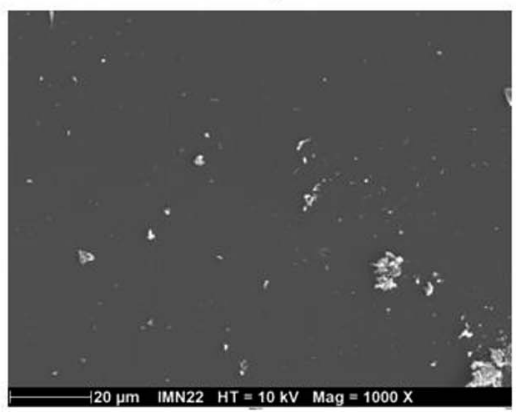

Fig. 2 SEM pictures of glass monoliths in the absence/presence of glass powder (GP) in S1b, S2b and S5 solution at $50{ }^{\circ} \mathrm{C}$ (Exp. 4 and 5).

network-shaped lines. These lines are related to an electrically charged zone, typically observed with this technique. Within this network, the formation of a honeycomb-shaped gel is observed. Micro-Raman analyses of both sides of the monolith surface indicate the presence of a phase with a low $\mathrm{Ca} / \mathrm{Si}$ ratio close to a chabazite-like phase, $\mathrm{Ca}_{2} \mathrm{Al}_{4} \mathrm{Si}_{8} \mathrm{O}_{24} \cdot 13 \mathrm{H}_{2} \mathrm{O}$. The low $\mathrm{Ca} / \mathrm{Si}$ ratio of 0.25 was confirmed via EDX analysis. In the absence of glass powder, EDX analysis reveals a composition similar to pristine glass, suggesting a very small thickness of glass alteration.

In solution S2b, SEM analysis on both sides of the monolith shows again the formation of a phyllosilicate-like alteration phase, but the thinness of the alteration layer precluded any obtaining of good EDX micro-analysis. Similar observations were found by Utton et al. on an ILW glass surface altered in same solution but at higher temperature $\left(70-90{ }^{\circ} \mathrm{C}\right) \cdot{ }^{31}$ MicroRaman analysis of the front side shows the formation of a tobermorite-like phase. In the absence of glass powder, calcite was identified via micro-Raman spectroscopy (an artefact due to probable contamination with atmospheric $\mathrm{CO}_{2}$ during analysis).

In S5 solution, an alteration layer consisting of phyllosilicates has been also observed via SEM on both sides. MicroRaman analyses on both sides indicate a very low $\mathrm{Ca} / \mathrm{Si}$ ratio, with a structure close to a gyrolite-like phase. These results are similar to those observed in the absence of glass powder.

Glass powder in contact with HCP (Exp. 6 and 7, Tables 3 and 5). Glass powder before and after alteration, in the presence and absence of HCP was characterized via X-ray diffraction after experiments at $50{ }^{\circ} \mathrm{C}$ (data not shown). In the absence of HCP, the glass powder altered in the three solutions S1b, S2b and S5 was characterized via XRD at the end of the experiments under the same conditions as those for HCP alone. The diffraction data show a typical glass signature with a wide peak between $2 \theta$ values of $13^{\circ}$ and $38^{\circ}$. Crystalline phases were not detected. In contact with the HCPs, only a calcite phase was identified in all $\mathrm{X}$-ray diffraction patterns, probably due to sample preparation and potential contamination from atmospheric $\mathrm{CO}_{2}$ during 
analysis. The glass powder and HCP were probably not dried enough prior to analysis, promoting the formation of calcite during storage before analysis. Portlandite, ettringite and analcime phases have not been detected, but their existence at trace levels cannot be excluded, as suggested by PhreeqC modelling. Finally, it can be noted that in S2b solution, ettringite disappears in the presence of glass powder, whereas this phase is present in CEM I and CEM V pastes only at $50{ }^{\circ} \mathrm{C}$.

Glass monoliths in contact with HCP (Exp. 8 and 9, Fig. 3, Tables 3 and 5). Fig. 3 shows the characteristics of the front and rear sides of a monolith surface in contact with HCP.

When in contact with CEM-I HCP powder in S1b solution, the surface of the monolith presents an altered layer made of phyllosilicate-like phases enriched with $\mathrm{Si}$ and Ca. Characterization by micro-Raman indicates the presence of a tobermorite-like phase $(\mathrm{Ca} / \mathrm{Si}: \sim 0.83)$. On the front side, direct contact with HCP powder promotes the formation of a supplementary hastingsite-like phase, $\mathrm{NaCa}_{2}\left(\mathrm{Fe}_{4}{ }^{2+} \mathrm{Fe}^{3+}\right)\left(\mathrm{Si}_{6} \mathrm{Al}_{2}\right) \mathrm{O}_{22}(\mathrm{OH})_{2}$. At the rear side, a $\mathrm{C}-\mathrm{S}-\mathrm{H}$ phase with a high $\mathrm{Ca} / \mathrm{Si}$ ratio of $\sim 1.7$ (ref. 31) is characterized via micro-Raman. ${ }^{56}$ In solution $\mathrm{S} 2 \mathrm{~b}$, an altered layer is formed on both sides of the monolith, with a high $\mathrm{Ca} / \mathrm{Si}$ ratio of 1.4-1.5 determined via EDX. The high concentration of $\mathrm{Ca}$ in S2b solution may be responsible for the increase in the $\mathrm{Ca} /$ $\mathrm{Si}$ ratio. Micro-Raman analysis shows an additional $\mathrm{C}-\mathrm{S}-\mathrm{H}$ phase with a low $\mathrm{Ca} / \mathrm{Si}$ ratio close to a tobermorite-like phase. On the rear side, the needle-like morphology of ettringite is observed via SEM and is confirmed from EDX and micro-Raman analyses. ${ }^{57}$

In contact with CEM-V HCP in S1b solution, an altered layer is observed on both sides via SEM with the presence of a tobermorite-like phase. The chemical composition determined via EDX is similar to pristine glass, indicating that the layer formed is very thin to be detected by EDX. In solution S2b, for both sides, the surface exhibits an altered layer with a phyllosilicate-like phase, with spherical precipitates and the needlelike morphology of ettringite. Analysis of the altered layer demonstrates a low $\mathrm{Ca} / \mathrm{Si}$ ratio tobermorite-like phase, confirmed via EDX and micro-Raman. These morphologies are reminiscent of those found by Utton on glass altered at $70{ }^{\circ} \mathrm{C}$ and $90{ }^{\circ} \mathrm{C}$ in $\mathrm{Ca}(\mathrm{OH})_{2}$ solution. ${ }^{31}$ The presence of CEM-V seems to accelerate the process of formation of these phases.

In contact with low-pH HCP in S5 solution, no altered layer is observed via SEM, however analysis via micro-Raman shows the signature of a gel layer. On the rear side, the glass shows precipitates enriched with $\mathrm{Si}$ and $\mathrm{Ca}$, with a low $\mathrm{Ca} / \mathrm{Si}$ ratio, close to a tobermorite-like phase.

Surface characterization of the monoliths via SEM and micro-Raman analysis is in good agreement with the results of PhreeqC modeling. It is of note that the ettringite exists at elevated temperature $\left(50{ }^{\circ} \mathrm{C}\right)$ in a solution enriched with calcium (typically, S2b solution) and in the presence of a tobermorite type phase, showing that in this particular environment ettringite may remain stable even at temperatures higher than $40{ }^{\circ} \mathrm{C:}^{52}$ the formation and stabilization of ettringite seem to be dependent on the presence of tobermorite. The mechanism of tobermorite formation generally occurs during the hydration processes of anhydrous calcium silicate phases such as $\mathrm{C}_{3} \mathrm{~S}$ 


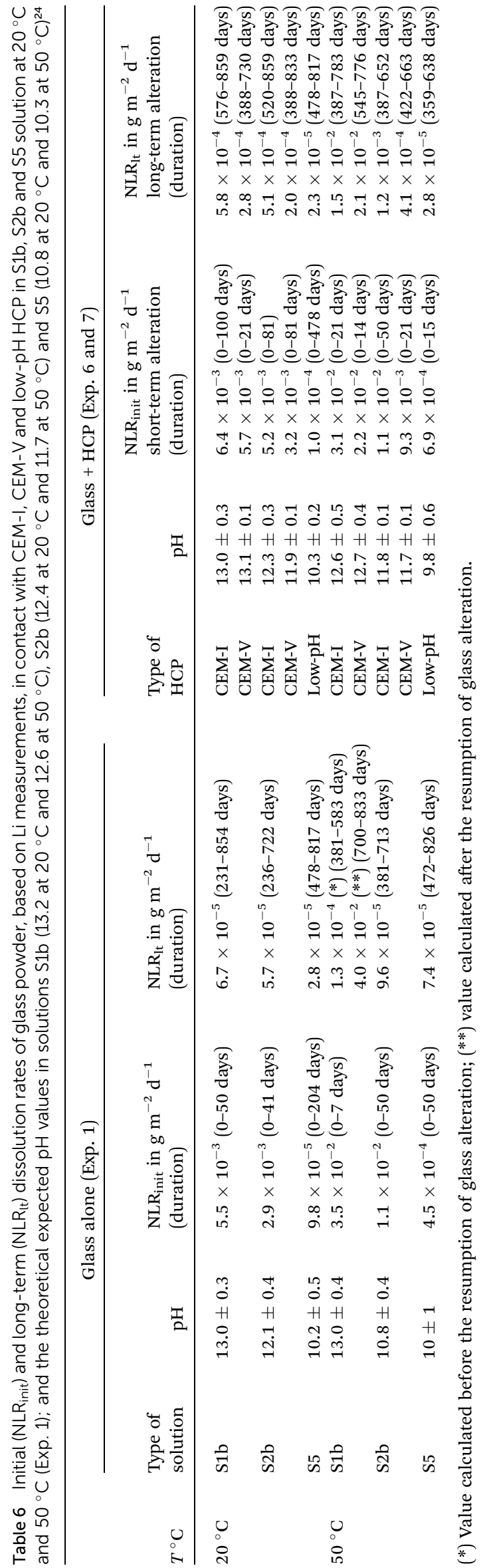




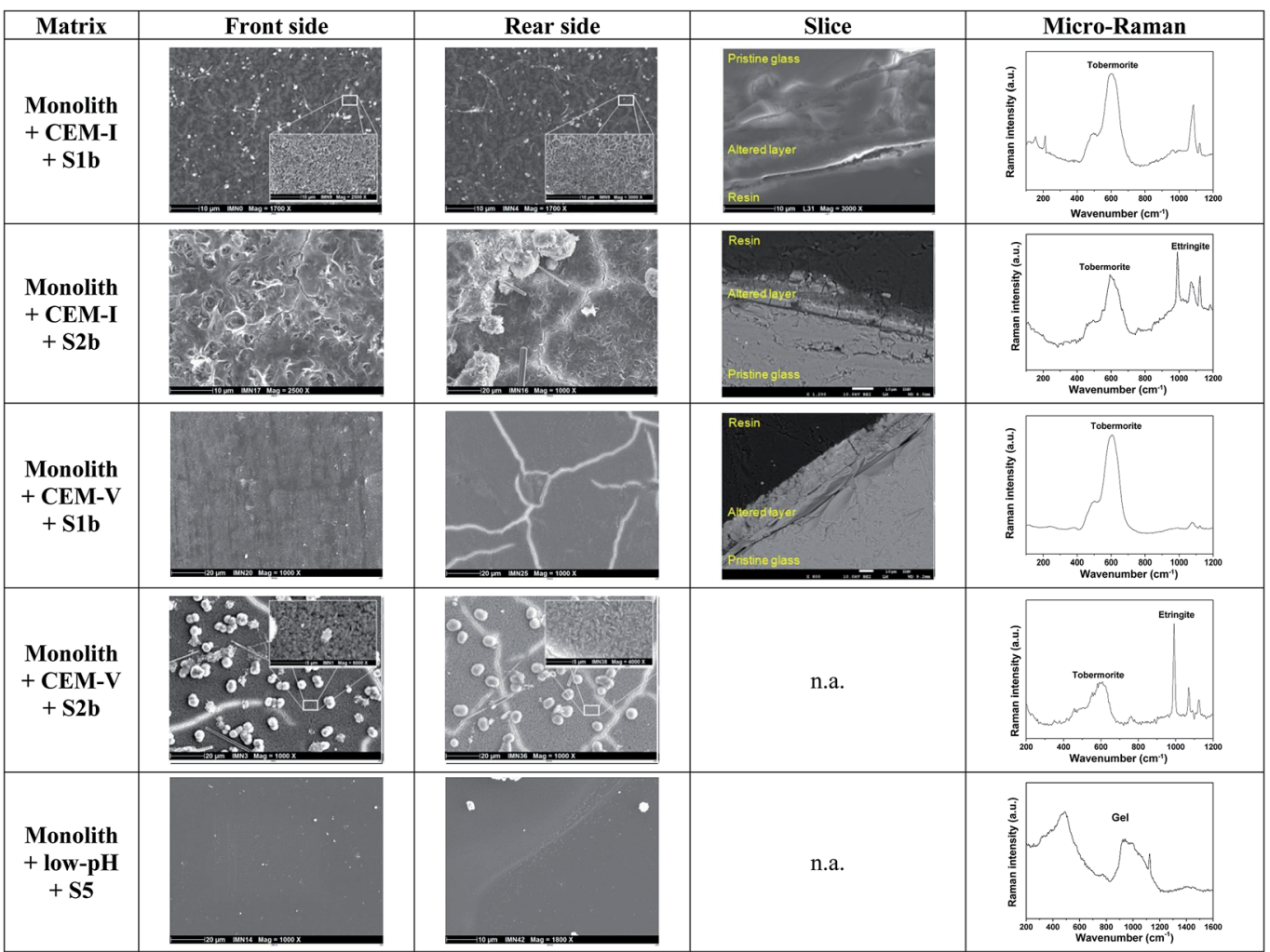

Fig. 3 Surface characterization of glass monoliths in contact with CEM-I, CEM-V and low-pH HCP in S1b, S2b and S5 solution at $50{ }^{\circ} \mathrm{C}$. n.a.: not available (Exp. 8 and 9).

$\left(3 \mathrm{CaO} \cdot \mathrm{SiO}_{2}\right)$ and $\mathrm{C}_{2} \mathrm{~S}\left(2 \mathrm{CaO} \cdot \mathrm{SiO}_{2}\right),{ }^{58,59}$ and is initiated by the presence of a $\mathrm{C}-\mathrm{S}-\mathrm{H}$ gel with a low $\mathrm{Ca} / \mathrm{Si}$ ratio $(<1)$, sustained by the presence of $\mathrm{Si}$ and $\mathrm{Al}$, alkaline media and sulfate compounds. ${ }^{60,61}$ In addition, the ageing of the $\mathrm{C}-\mathrm{S}-\mathrm{H}$ gel gives rise to a final product, which is tobermorite at a low $\mathrm{Ca} / \mathrm{Si}$ ratio $(<1)$ or jennite at a high $\mathrm{Ca} / \mathrm{Si}$ ratio $(>1)$, and intermediate phases, which are afwillite, gyrolite and xonotlite. ${ }^{40,61}$ In this present study, the formation of tobermorite was observed as the main $\mathrm{C}-\mathrm{S}-\mathrm{H}$ phase formed during alteration due to the chemical conditions of the systems: $\mathrm{Si}$ was released by glass and HCP alteration; Ca from solution (S1b, S2b); and Al by CEM-I and CEM-V HCPs and glass dissolution.

\subsection{Glass alteration}

3.2.1. Lithium: a good tracer of glass alteration in cementitious media. The principal indicators of glass alteration are the determination of the normalized mass loss $\left(\mathrm{NL}_{\mathrm{i}}\right)$, initial $\left(\mathrm{NL}_{\text {init }}\right)$, and long-term $\left(\mathrm{NL}_{\mathrm{lt}}\right)$ alteration rates, and the equivalent alteration thicknesses. In general, Si and B (network formers) and $\mathrm{Na}$ and $\mathrm{Li}$ (network modifiers) are measured in solution, due to their good mobility and the absence of their retention on the alteration layer. ${ }^{7,15,35}$ In particular, boron is usually considered a good tracer of glass alteration over a large wide $\mathrm{pH}$ value range (acidic to low alkaline $\mathrm{pH})^{18,52}$ and at temperatures up to $300{ }^{\circ} \mathrm{C}$ (ref. 53) due to the absence of precipitation of secondary phases considering the repository conditions. ${ }^{54}$ However, the results of this work reveal that boron may not be a suitable tracer of glass alteration compared to lithium when experiments are conducted in cementitious media. The nature of the solution composition, notably as a result of $\mathrm{Ca}$ enrichment, associated with the presence of hardened cement paste types containing portlandite and aluminate phases, may modify the mechanisms of boron release in solution and the possible precipitation of boron in secondary phases, such as a calcium borate phase. The non-congruent release of $\mathrm{Li}$ and $\mathrm{B}$ has been also observed during the alteration of ILW glass in $\mathrm{Ca}(\mathrm{OH})_{2}$ solution in the work of Utton et al. ${ }^{31}$ Therefore, the choice of a tracer representative of the glass alteration needs to be carefully considered for the determination of alteration rates, as well as the equivalent altered thicknesses. The authors wish to draw attention to this issue and not to overlook the importance of measuring all significant glass tracers (Li, B and Mo), when possible. Therefore, in this work, due to the multiplicity of studied systems with different solution compositions and hardened cement pastes, all calculations regarding the evaluation of alteration rates as well as the equivalent altered thicknesses are based on lithium data instead of boron as is commonly done.

3.2.2. Evolution of $\mathbf{p H}$. Table 6 reports $\mathrm{pH}$ values measured during glass alteration experiments in solutions S1b, S2b and S5, in the absence and presence of HCP at $20^{\circ} \mathrm{C}$ and $50{ }^{\circ} \mathrm{C}$ (Exp. 1, 6 and 7). These values have been averaged over the whole duration of each experiment, up to 900 days. Besides, the experimental values correspond to the expected levels calculated through geochemical modelling, ${ }^{62}$ with acceptable uncertainty ranges. The good stability of the $\mathrm{pH}$ values reveals that the method of sampling in a glove box free of $\mathrm{CO}_{2}(\mathrm{~g})$ and the conditioning of the experimental systems in Teflon ${ }^{\circledR}$ vials 
(a) Glass powder $+\mathrm{S} 1 \mathrm{~b} ; 20^{\circ} \mathrm{C}$

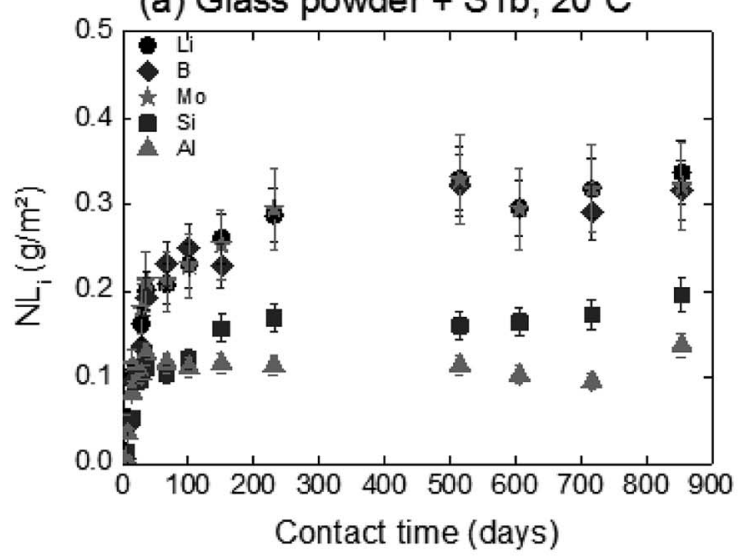

(b) Glass powder $+\mathrm{S} 2 \mathrm{~b} ; 20^{\circ} \mathrm{C}$

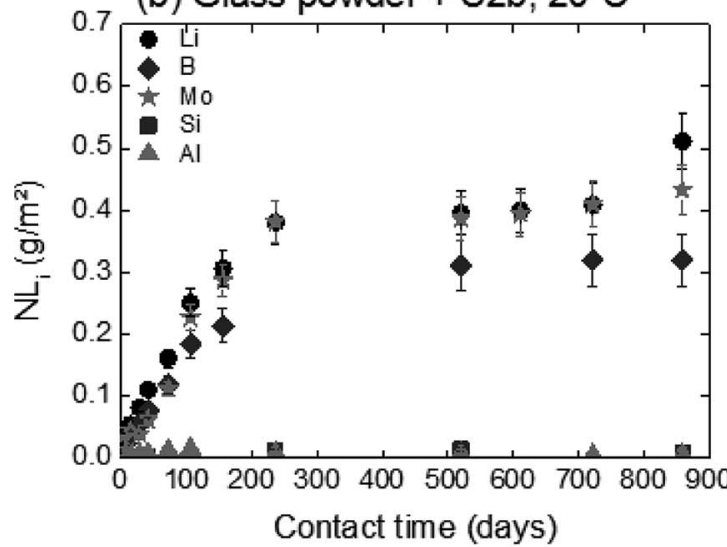

(c) Glass powder $+\$ 5 ; 20^{\circ} \mathrm{C}$

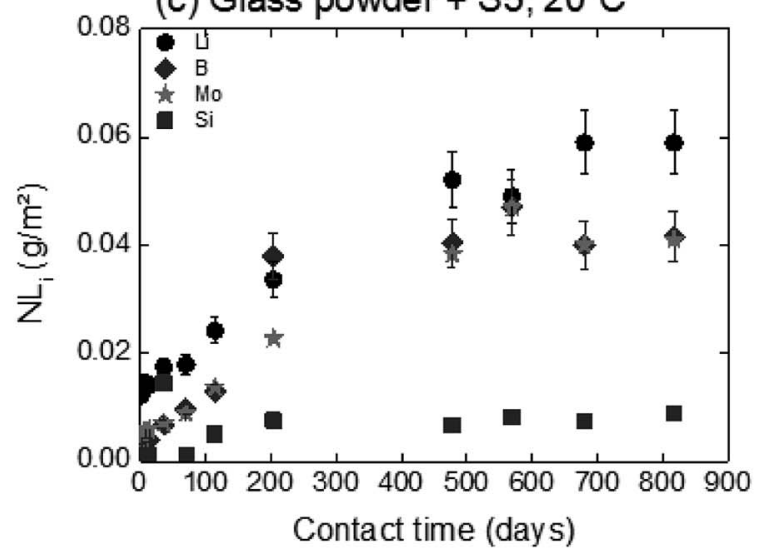

(d) Glass powder + CEM-I $+S 1 b ; 20^{\circ} \mathrm{C}$

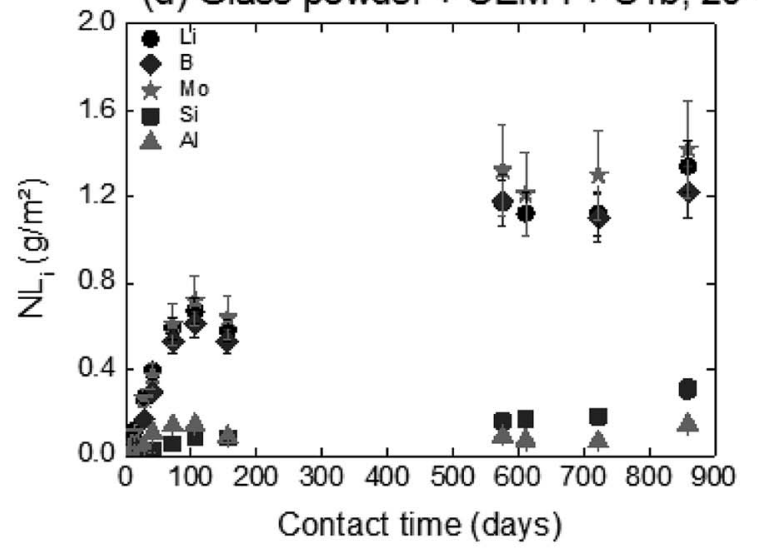

(e) Glass powder + CEM-I + S2b;20 2
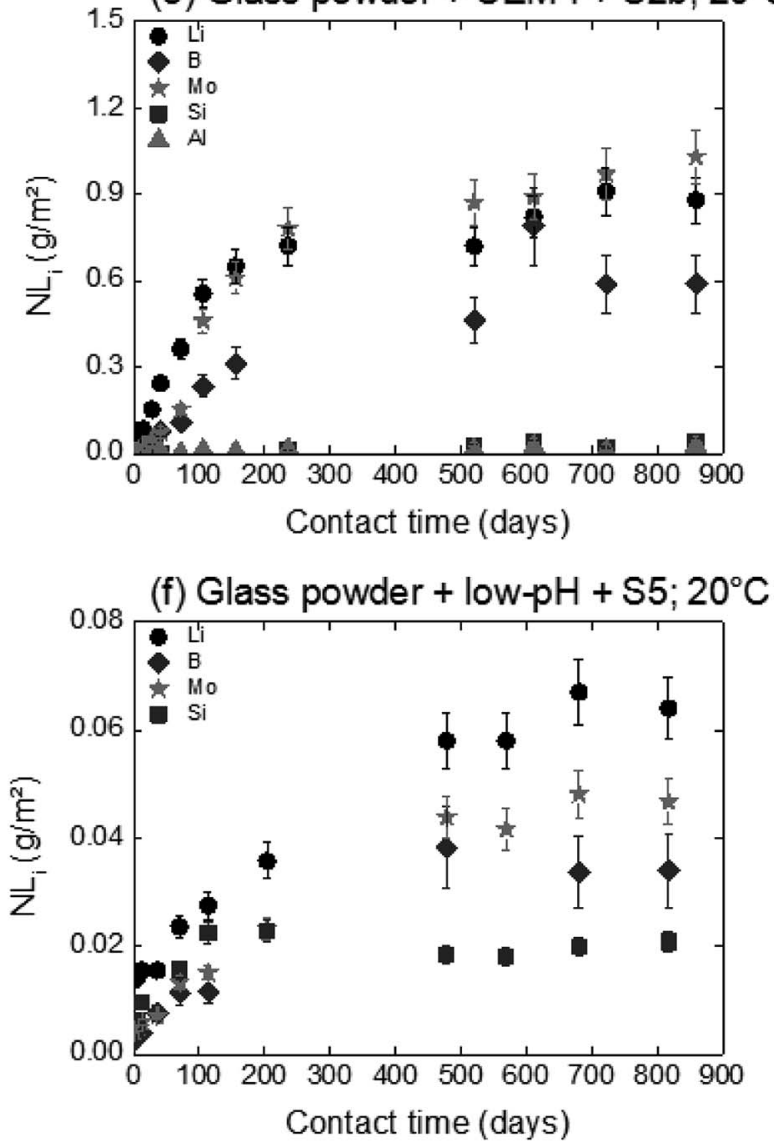

Fig. 4 Normalized mass loss of selected elements during glass powder dissolution in S1b, S2b and S5 solution at $20^{\circ} \mathrm{C}$ in the absence (Exp. 1 ) and presence of CEM-I, CEM-V and low-pH HCP (Exp. 6 and 7).

allows the systems to remain undisturbed, even after 3 years of experiments, notably regarding the possible contamination of solutions with $\mathrm{CO}_{2}(\mathrm{~g})$. In particular, the $\mathrm{pH}$ values in $\mathrm{S} 5$ solution in contact with low-pH HCP (Exp. 7) remained constant at about $10.2 \pm 0.1$ at $20^{\circ} \mathrm{C}$ and $9.8 \pm 0.6$ at $50{ }^{\circ} \mathrm{C}$, which are consistent with those found in the literature. Vuorinen et al. measured the $\mathrm{pH}$ in neutral groundwater, saline reference groundwater and simulated fresh granitic groundwater solutions during leaching experiments involving low-pH cements and found final $\mathrm{pH}$ values between 10.9 and $11.3 .^{50}$ The low-pH values found in cementitious aqueous media are also confirmed in the work of Calvo et al., who obtained a value of $9 .{ }^{51}$. In solutions S1b and $\mathrm{S} 2 \mathrm{~b}$, the values remain high: about $12-13$ for $\mathrm{S} 1 \mathrm{~b}$ and less than 12 for $\mathrm{S} 2 \mathrm{~b}$; these high $\mathrm{pH}$ values are known to increase silicate glass solubility.

\subsection{Effects of the solution composition of S5 solution versus S1b and S2b solution}

The influence of solution composition related to the $\mathrm{pH}$ effect on glass powder alteration was assessed using the binary system 
(glass/solution). The tracers of glass alteration, Li, B and Mo, are monitored in S1b, S2b and S5 solution at $20{ }^{\circ} \mathrm{C}$ and $50{ }^{\circ} \mathrm{C}$ (Exp. 1). Fig. 4(a)-(c) show the evolution of the normalized mass loss of selected elements in S1b, S2b and S5 solution at $20{ }^{\circ} \mathrm{C}$. Similar results are obtained at $50{ }^{\circ} \mathrm{C}$ (not shown here).

In solutions $\mathrm{S} 1 \mathrm{~b}$ and $\mathrm{S} 2 \mathrm{~b}, \mathrm{~B}, \mathrm{Li}$ and $\mathrm{Mo}$ are released congruently throughout the experiment duration. The shortterm alteration rates of glass powder $\left(\mathrm{NLR}_{\text {init }}\right)$ between 0 and 50 days are $5.5 \times 10^{-3} \mathrm{~g} \mathrm{~m}^{-2} \mathrm{~d}^{-1}$ in S1b solution and $2.9 \times$ $10^{-3} \mathrm{~g} \mathrm{~m}^{-2} \mathrm{~d}^{-1}$ in $\mathrm{S} 2 \mathrm{~b}$ solution at $20^{\circ} \mathrm{C}$, and $3.5 \times 10^{-2} \mathrm{~g} \mathrm{~m}^{-2}$ $\mathrm{d}^{-1}$ in S1b solution and $1.1 \times 10^{-2} \mathrm{~g} \mathrm{~m}^{-2} \mathrm{~d}^{-1}$ in $\mathrm{S} 2 \mathrm{~b}$ solution at $50{ }^{\circ} \mathrm{C}$ (Table 6). The solution composition and the $\mathrm{pH}$ effects are key parameters relating to the dissolution process and they have been assessed in the literature. ${ }^{63}$ Typical initial alteration rates under batch conditions are in the range of $\sim 10^{-2} \mathrm{~g} \mathrm{~m}^{-2} \mathrm{~d}^{-1}$ between $25-90{ }^{\circ} \mathrm{C}$ near neutral $\mathrm{pH}$, and they increase significantly with $\mathrm{pH}^{6,45}$ However, these values evolve as a function of the composition of the leaching solution; in particular the initial alteration rates tend to be lower in highly concentrated alkali solutions. In the presence of $\mathrm{Ca}, \mathrm{K}$, and $\mathrm{Na}$, representative of solution $\mathrm{S} 1 \mathrm{~b}$, the surface of the glass develops resistance to corrosion via the direct adsorption of these elements at the surface. This mechanism avoids, therefore, the first reactions of inter-diffusion and hydrolysis, resulting in the formation of a protective layer. ${ }^{63}$

In solution S5, the normalized mass loss values of glass obtained are 10 times lower than those measured in solutions S1b and S2b: $9.8 \times 10^{-5} \mathrm{~g} \mathrm{~m}^{-2} \mathrm{~d}^{-1}$ at $20{ }^{\circ} \mathrm{C}$ and $4.5 \times 10^{-4} \mathrm{~g}$ $\mathrm{m}^{-2} \mathrm{~d}^{-1}$ at $50{ }^{\circ} \mathrm{C}$. Fig. 5 shows the Li-concentration released from glass powder in the absence of $\mathrm{HCP}$ at $50^{\circ} \mathrm{C}$ in solution S5. The results are compared with those obtained in solutions S1b and S2b and are represented as a function of the square root of the contact time in the binary system (glass/solution). In solution S5, there is a linear correlation between the Li concentration and the square root of time, indicating a diffusive type $\mathrm{Li}$ release regime during glass alteration. In general, the so-called interdiffusion phase occurs in the first hours of glass alteration, when the cation modifiers of the glass network, which are the least bound, are released in solution. The reaction is then governed by an exchange of a proton with an alkaline element, here lithium, based on the reaction:

$$
\mathrm{Si}-\mathrm{O}-\mathrm{Li}+\mathrm{H}^{+} \leftrightarrow \mathrm{Si}-\mathrm{O}-\mathrm{H}+\mathrm{Li}^{+}
$$

This reaction also shows that this is promoted in an acidic and neutral environment. However, the results of the alteration experiments in S5 solution with a pH of 9-10 show that a continuous diffusion mechanism can be expected throughout the duration of the experiment, i.e., over nearly 850 days.

3.3.1. Effects of temperature. For all systems without HCP, an increase in the initial glass dissolution rates occurred going from $20{ }^{\circ} \mathrm{C}$ to $50{ }^{\circ} \mathrm{C}$, by a factor of 4 to 6 . The long-term dissolution rates $\left(\mathrm{NLR}_{\mathrm{lt}}\right)$ are also higher at $50{ }^{\circ} \mathrm{C}$ than at $20^{\circ} \mathrm{C}(2$ to 3 times higher). In particular, the experiment involving glass dissolution in $\mathrm{S} 1 \mathrm{~b}$ at $50{ }^{\circ} \mathrm{C}$ shows a resumption of glass alteration observed after 700 days with a significant increase in $\mathrm{Li}, \mathrm{B}$, Mo and Si normalized mass losses, a significant decrease in $\mathrm{Al}$

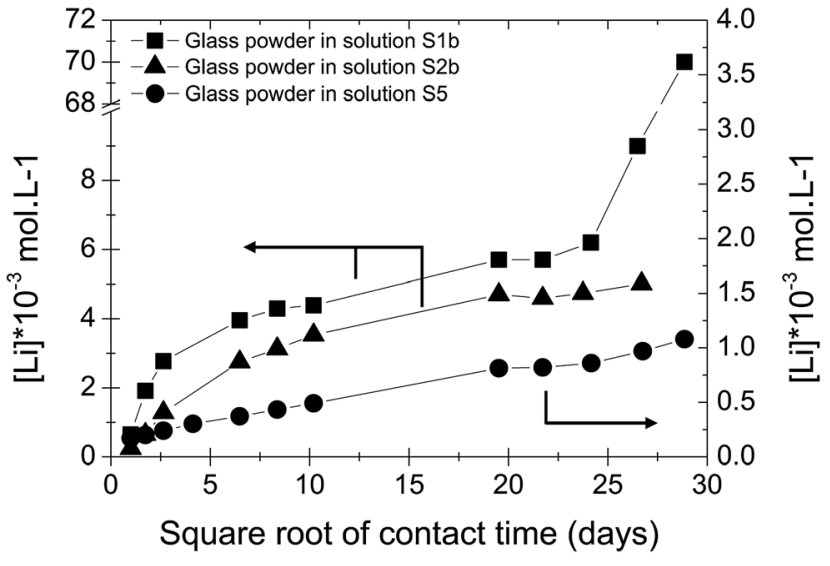

Fig. 5 Concentration of Li released from glass powder as a function of the square root of contact time in S1b, S2b and S5 solution at $50{ }^{\circ} \mathrm{C}$ (Exp. 1)

normalized mass loss, and a pH decrease from 13.1 to 12.2. Fig. 6 presents the correlation between the normalized mass loss of glass powder dissolution in S1b solution and $\mathrm{pH}$. Saturation calculations via PhreeqC modelling from results obtained in solution reveal that analcime $\left(\mathrm{NaAlSi}_{2} \mathrm{O}_{6} \cdot \mathrm{H}_{2} \mathrm{O}\right)$ may be the phase controlling the resumption of glass alteration. Although this phase was not observed via X-ray diffraction and micro-Raman characterization, this result is in good agreement with the review paper of Fournier et al. dedicated to state of art research into resumption in nuclear glass waste. ${ }^{55}$ In particular, the authors attribute this phenomenon to the combined effect of glass and solution composition and temperature. ${ }^{55}$ The high content of $\mathrm{Al}$ and $\mathrm{Na}$ enrichment in ILW pristine glass compared to SON68 glass is one of the precursors of the resumption mechanism, associated with high $\mathrm{pH}$ solution $\mathrm{pH}$ $>$ 11.5). ${ }^{55}$ The resumption of the glass alteration may decrease the $\mathrm{pH}$ of the leaching solution. No such resumption effect has been observed in S2b or S5 solution.

For experiments in the presence of hydrated cement pastes (CEM-I, CEM-V and low-pH), the same trend is observed with short-term dissolution rates at $50{ }^{\circ} \mathrm{C}$ ( 4 to 7 times higher than at $20{ }^{\circ} \mathrm{C}$ ) with $\mathrm{S} 1 \mathrm{~b}$ and S5 solutions. For solution S2b, the temperature effect on glass dissolution seems to be counterbalanced by a slight decrease in the $\mathrm{pH}$ value from 12.1 at $20{ }^{\circ} \mathrm{C}$ to 11.8 at $50{ }^{\circ} \mathrm{C}$; the latter is less aggressive with regard to glass dissolution. The short-term dissolution rates in S2b (CEM-I, CEM-V) at $50{ }^{\circ} \mathrm{C}$ are then only $2-3$ times higher than at $20^{\circ} \mathrm{C}$.

For long-term dissolution rates at $50{ }^{\circ} \mathrm{C}$, no steady-state in the ternary system (glass/HCP/S1b; Exp. 4) is reached, even after 776 days of experiments. The long-term dissolution rates are 26 to 75 times higher at $50{ }^{\circ} \mathrm{C}$ than at $20^{\circ} \mathrm{C}$ for CEM I and CEM V. As an example, Fig. 7 presents the normalized mass loss of glass powder dissolution in $\mathrm{S} 1 \mathrm{~b}$ solution at $50{ }^{\circ} \mathrm{C}$ in the presence of CEM-I HCP.

3.3.2. Effects of the presence of HCP. Similarly to the glass alteration studies, HCP leaching experiments were performed in the binary system ( $\mathrm{HCP} /$ solution), in which concentrations of $\mathrm{Li}, \mathrm{B}, \mathrm{Al}, \mathrm{Si}$ and Mo leached into S1b, S2b or S5 solution were assessed at $20{ }^{\circ} \mathrm{C}$ and $50{ }^{\circ} \mathrm{C}$ (Exp. 2 and 3, Table 7). Batch 
experiments were conducted in the respective solutions for 730950 days. Table 7 presents the mean concentrations in $\mathrm{Li}, \mathrm{B}, \mathrm{Al}$, $\mathrm{Si}$, and Mo. The main trends are as follows:

- Lithium is released instantaneously into the solutions at $20{ }^{\circ} \mathrm{C}$ and $50{ }^{\circ} \mathrm{C}$ at about $10^{-5} \mathrm{~mol} \mathrm{~L}^{-1}$;

- The boron concentration is only measured at $50{ }^{\circ} \mathrm{C}$ to have an average concentration of $10^{-5} \mathrm{~mol} \mathrm{~L}^{-1}$;

- The molybdenum concentration is very low, with a mean value between $10^{-7}$ and $10^{-8} \mathrm{~mol} \mathrm{~L}^{-1}$;

- The aluminum concentration varies with solution type, HCP type and temperature $\left(10^{-6}\right.$ to $\left.10^{-3} \mathrm{~mol} \mathrm{~L}^{-1}\right)$.

In the same way, the silicon concentration directly depends on the HCP type. In the presence of CEM-I HCP, the total concentration measured in solutions $\mathrm{S} 1 \mathrm{~b}$ and $\mathrm{S} 2 \mathrm{~b}$ at $50{ }^{\circ} \mathrm{C}$ is 6 $\times 10^{-5} \mathrm{~mol} \mathrm{~L}^{-1}$. This value is an order of magnitude higher than the expected value calculated via geochemical models. ${ }^{62}$ For low-pH HCP, the concentration value is high, $1 \times 10^{-3} \mathrm{~mol} \mathrm{~L}^{-1}$, which corresponds to the solubility value of amorphous silica. ${ }^{62}$ This is consistent with the low-pH HCP composition (30\% silica fume), in which hydration leads to the formation of amorphous silica. Amorphous silica represents a third of the total mass of the low-pH cement paste.

A comparison of glass dissolution rates obtained for binary (glass/solution) and ternary (glass/HCP/solution) systems shows two trends (Fig. 4, Table 6): (1) short-term rates are almost

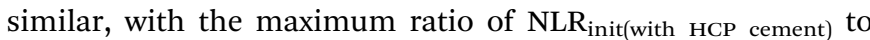
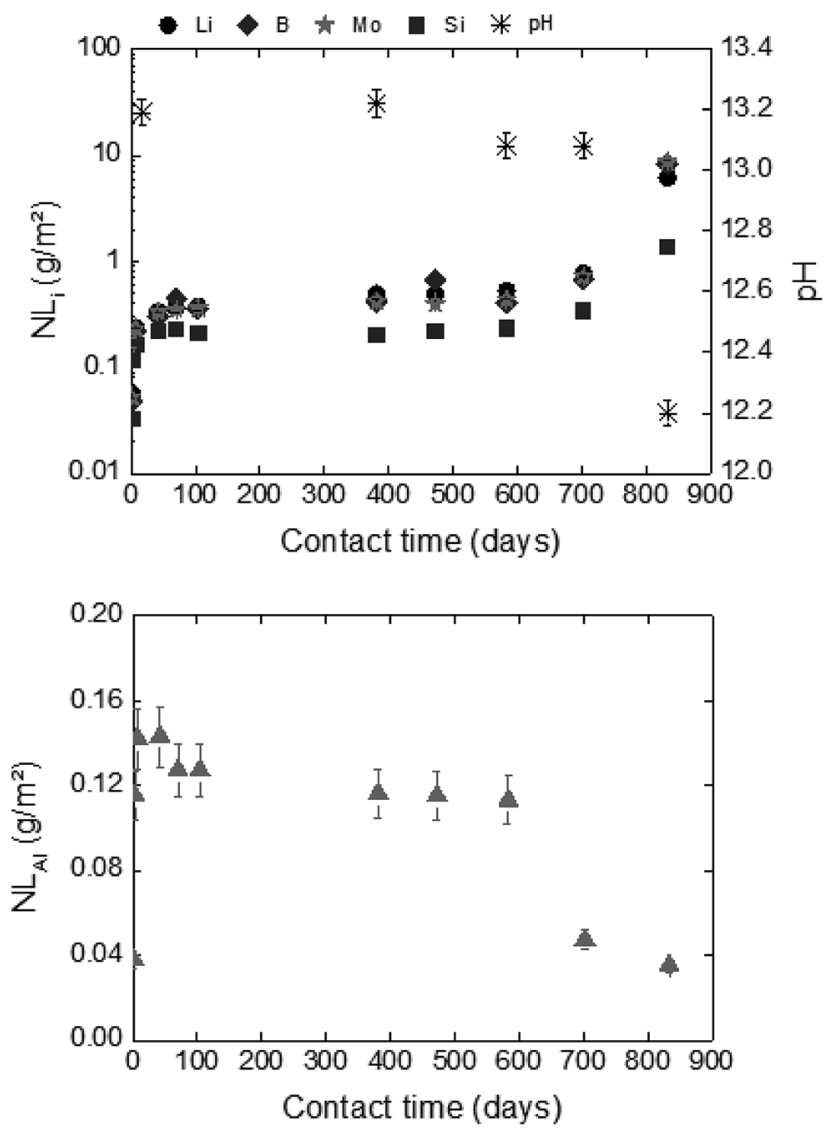

Fig. 6 Normalized mass loss of glass powder dissolution in solution $\mathrm{S} 1 \mathrm{~b}$ at $50^{\circ} \mathrm{C}$ (Exp. 1).
$\mathrm{NLR}_{\text {init(no HCP) }}$ not exceeding 1.8, and (2) long-term rates are higher for ternary systems with $\mathrm{S} 1 \mathrm{~b}$ and $\mathrm{S} 2 \mathrm{~b}$ solution. As an example, in the system with solution S1b and CEM-I or CEM-V, dissolution rates at $50{ }^{\circ} \mathrm{C}$ are higher than those in solution alone by factors of 115 and 162, respectively. Furthermore, the difference in dissolution rates between S1b (+HCP) and S2b (+HCP) can be explained by the difference in $\mathrm{pH}$, which is higher for $\mathrm{S} 1 \mathrm{~b}(\mathrm{pH}=12.6)$ than for $\mathrm{S} 2 \mathrm{~b}(\mathrm{pH} 11.6$, see Table 2). Another parameter to take into account is that the Ca concentration is 10 times higher in S2b than in S1b solution. Calcium in cementitious systems is known to counterbalance the effects of high $\mathrm{pH}$ on glass dissolution by structuring the gel layer formed on the glass surface, thus slowing down water diffusion into the glass matrix. ${ }^{28,33}$ The $\mathrm{S} 5$ solution/low-pH cement system had no effect on glass long-term dissolution. This could be attributed to both the low $\mathrm{pH}$ value $(\mathrm{pH}=9.8)$ and high silica content in the low-pH HCP, leading to high silica concentrations in solution $\left(2 \times 10^{-3} \mathrm{~mol} \mathrm{~L}^{-1}\right)$.

3.3.3. The role of calcium silicate hydrate $(\mathrm{C}-\mathrm{S}-\mathrm{H})$. In binary systems (HCP/solution), HCPs are brought into equilibrium with solution, which may lead to the dissolution of sulfoaluminate phases such as ettringite/AFm at $50{ }^{\circ} \mathrm{C}$ or to changes in $\mathrm{C}-\mathrm{S}-\mathrm{H}$ phase structures. Geochemical modelling suggests that $\mathrm{C}-\mathrm{S}-\mathrm{H}$ phases are the main precipitating phases, which was experimentally confirmed and presented in the solid characterization section. Hence, in the binary systems S1b + CEM-I and S1b + CEM-V, the silicon concentration seems to be controlled by the $\mathrm{C}-\mathrm{S}-\mathrm{H}$ phases, with $\mathrm{Ca} / \mathrm{Si}=1.6$ and 1.2 at $20{ }^{\circ} \mathrm{C}$ and $50{ }^{\circ} \mathrm{C}$, respectively. In solution $\mathrm{S} 2 \mathrm{~b}$, the $\mathrm{C}-\mathrm{S}-\mathrm{H}$ phase with $\mathrm{Ca} / \mathrm{Si}=1.6$ is expected to precipitate at $20^{\circ} \mathrm{C}$. At $50{ }^{\circ} \mathrm{C}$, the nature of $\mathrm{C}-\mathrm{S}-\mathrm{H}$ is not clear, and it could be similar to phases with $\mathrm{Ca} / \mathrm{Si}=0.8$ to 1.2 . Aluminum and sulfate concentrations are controlled by the precipitation of ettringite and mono-sulfoaluminate. In solution S5, the silicon concentration is controlled by a quartz or cristobalite phase associated with $\mathrm{C}-\mathrm{S}-\mathrm{H}$ with a $\mathrm{Ca} / \mathrm{Si}=0.8$ phase at $20^{\circ} \mathrm{C}$ and $50{ }^{\circ} \mathrm{C}$. The calcium concentration is probably controlled by a $\mathrm{C}-\mathrm{S}-\mathrm{H}$-type phase. Concerning the phase controlling the concentration of

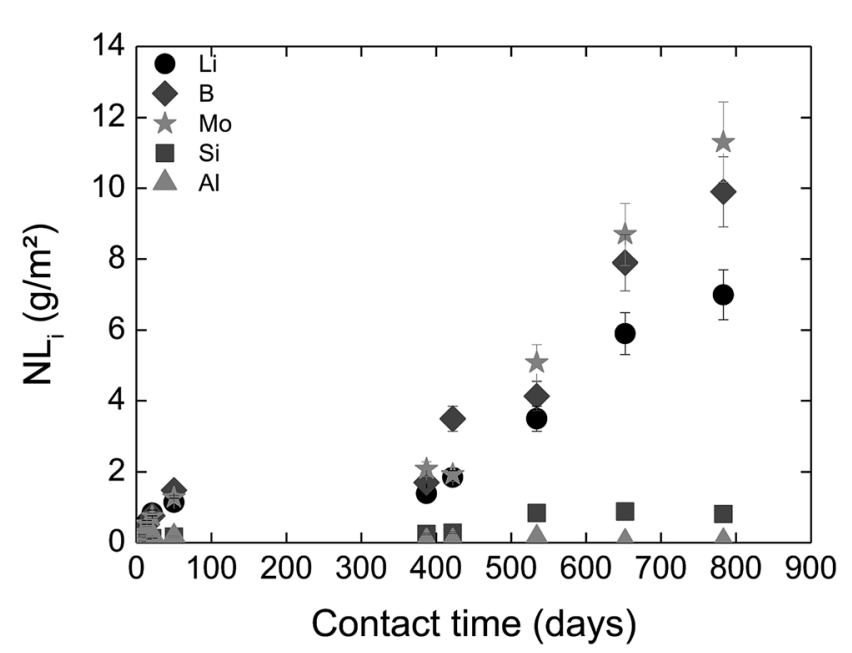

Fig. 7 Normalized mass loss of glass powder dissolution in S1b solution at $50{ }^{\circ} \mathrm{C}$ in the presence of CEM-I HCP powder (Exp. 6). 
Table $7 \mathrm{Li}, \mathrm{B}, \mathrm{Mo}$, Si, and Al concentrations $\left(\mathrm{mol} \mathrm{L}^{-1}\right)$ released from $\mathrm{HCP}$ during alteration experiments (S1b, S2b, and S5 solutions at $20{ }^{\circ} \mathrm{C}$ and 50 ${ }^{\circ}$ C) (Exp. 2 and 3)

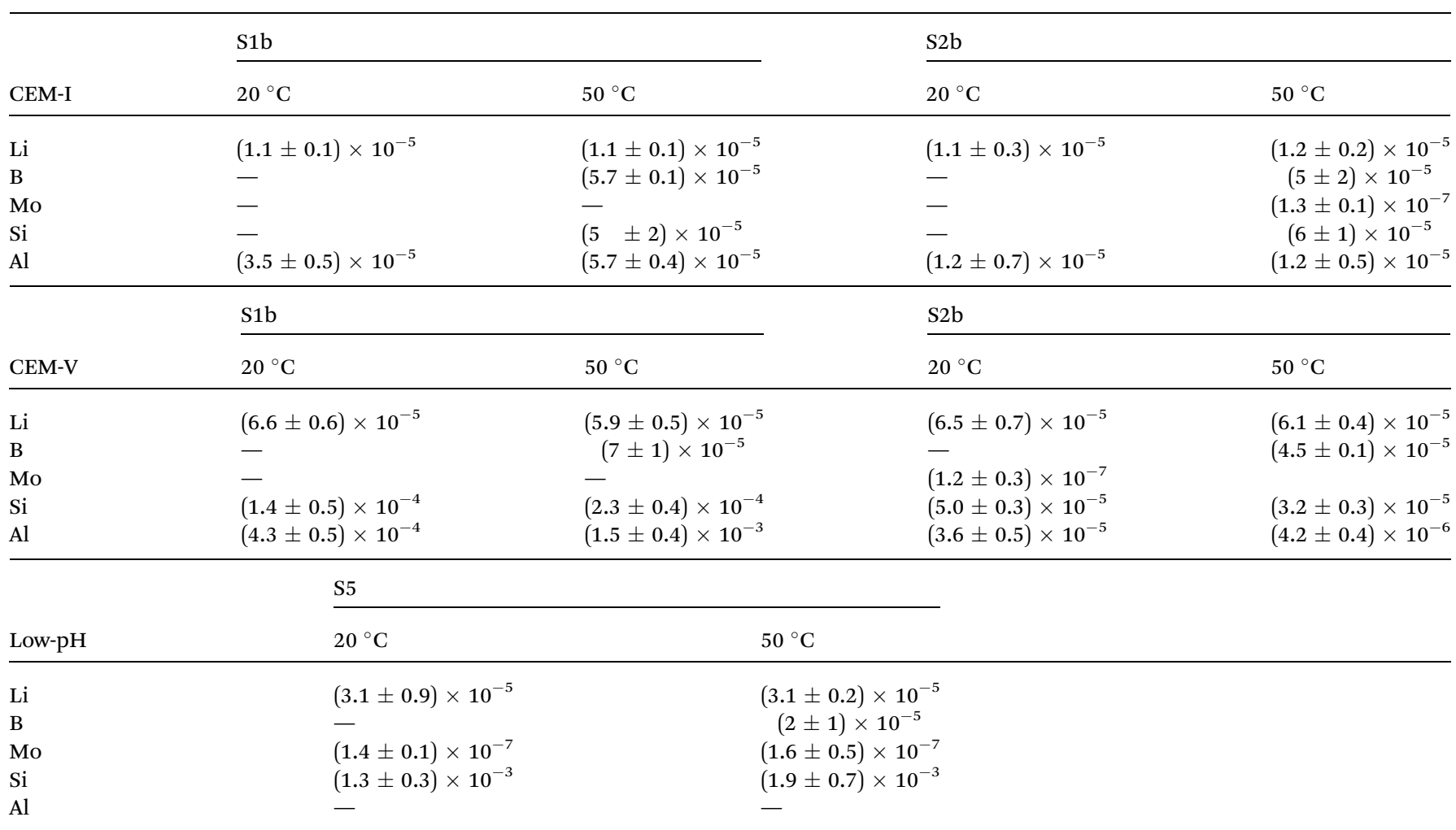

aluminum, modelling reveals that ettringite and mono-sulfoaluminate are not stable and tend to dissolve entirely. However, since the Al concentration does not increase, this suggests the control of $\mathrm{Al}$ in solution through the precipitation of a gibbsite $\mathrm{Al}(\mathrm{OH})_{3}$ phase.

To summarize, one can state that $\mathrm{C}-\mathrm{S}-\mathrm{H}$ phases are expected to precipitate in all systems with a higher $\mathrm{Ca} / \mathrm{Si}$ ratio at $50{ }^{\circ} \mathrm{C}$ than at $20{ }^{\circ} \mathrm{C}$, which could contribute to a glass dissolution increase at $50{ }^{\circ} \mathrm{C}$. In the S5-low-pH system, the higher silica concentration is controlled by crystalline silica phases rather than by $\mathrm{C}-\mathrm{S}-\mathrm{H}$ phases, which partially explains the difference in glass dissolution kinetics.

3.3.4. Equivalent altered thicknesses. Fig. 8 presents the equivalent altered thicknesses of glass powder with and without

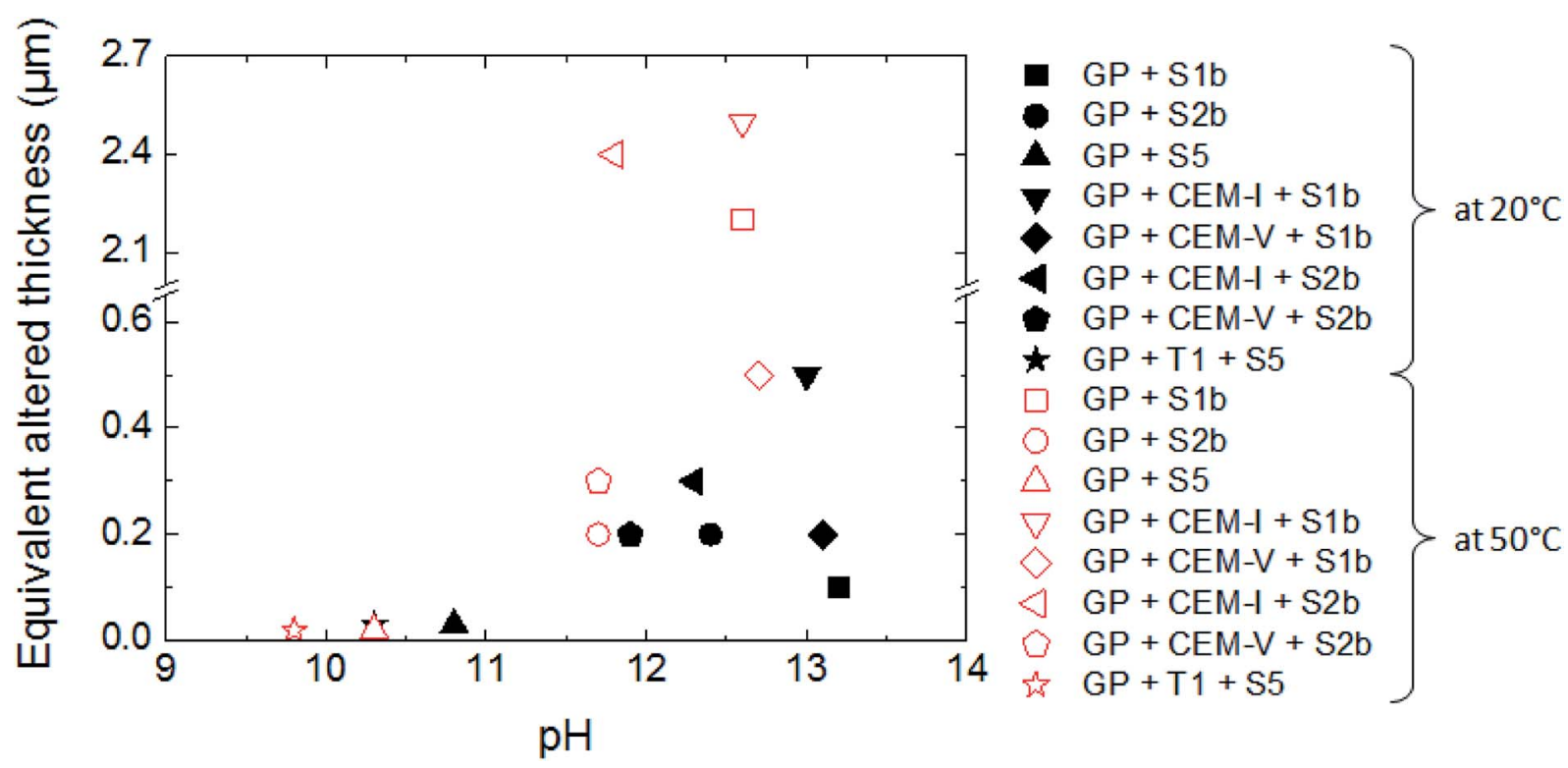

Fig. 8 The equivalent altered thickness of glass powder (GP) as a function of pH: the effects of S1b, S2b and S5 solution compositions, the presence of CEM-I, CEM-V and low-pH HCP powder, and temperature (Exp. 1, 5, 6 and 7). 
HCP. Between pH 9.5 and 11.0, the equivalent altered thickness ranges from 0.02 to $0.03 \mu \mathrm{m}$ in the absence and presence of low$\mathrm{pH}$ HCP after 638 to 833 days of alteration at $20{ }^{\circ} \mathrm{C}$ and $50{ }^{\circ} \mathrm{C}$, i.e., mean equivalent altered thickness rates between 0.02 and $0.05 \mathrm{~nm} \mathrm{~d}^{-1}$. Between $\mathrm{pH} 11.5$ and 13.5, the equivalent altered thickness of glass powder increases from 0.1 to $2.5 \mu \mathrm{m}$ (a factor of 5-125), due to temperature effects, the $\mathrm{pH}$ and the consequences of glass alteration resumption. Moreover, the highest equivalent altered thickness values are attributed to glass altered at $50{ }^{\circ} \mathrm{C}$ in high alkaline $\mathrm{S} 1 \mathrm{~b}$ solution. Average equivalent altered thickness rates are estimated between 0.2 and $0.6 \mathrm{~nm} \mathrm{~d}^{-1}$ in the absence of glass alteration resumption. Considering resumption phenomena, the equivalent altered thickness rates increase to $2.5-3.7 \mathrm{~nm} \mathrm{~d}^{-1}$. For comparison, the "resumption dissolution rates" are of the same order of magnitude as the initial dissolution rates (Table 3). For example, for the binary system (glass $+\mathrm{S} 1 \mathrm{~b}, 50{ }^{\circ} \mathrm{C}$ ), the "resumption dissolution rate" is equivalent to $4.0 \times 10^{-2} \mathrm{~g} \mathrm{~m}^{-2}$ $\mathrm{d}^{-1}$ between 700 and 833 days of alteration, which is close to the initial dissolution rate of $3.5 \times 10^{-2} \mathrm{~g} \mathrm{~m}^{-2} \mathrm{~d}^{-1}$ between 0 and 7 days. Finally, the results confirm that the higher the solution $\mathrm{pH}$ and temperature, the thicker the equivalent altered layer.

\section{Conclusions}

Intermediate level waste (ILW) glass dissolution in cementitious systems has been studied under different conditions that could be encountered during deep geological disposal, with relation to temperature, solution chemistry, and cement composition.

In the scenario of a repository of intermediate level vitrified waste, water re-saturation of the site starts with the degradation of cement, leading to highly alkaline pore water (solution S1b), followed by the control of the system by portlandite, with a lower $\mathrm{pH}$ of 12.4 (solution S2b). During long-term alteration, the $\mathrm{pH}$ is controlled by $\mathrm{C}-\mathrm{S}-\mathrm{H}$ phases and decreases to 9. This work shows that the dissolution of glass powder is influenced by the composition and the $\mathrm{pH}$ of solutions $\mathrm{S} 1 \mathrm{~b}(\mathrm{pH} 13), \mathrm{S} 2 \mathrm{~b}(\mathrm{pH}$ 12.4) and $\mathrm{S} 5(\mathrm{pH} 9)$ : the dissolution rates and the equivalent altered thicknesses increase with $\mathrm{pH}$.

This study gives some information about the potential influence of the different solutions on glass alteration. In contact with HCP (CEM-I and CEM-V) in solution S1b, a steady state is not reached, even after 776 days of alteration. In solution $\mathrm{S} 2 \mathrm{~b}$, classical tracers of glass dissolution ( $\mathrm{Li}, \mathrm{B}$ and $\mathrm{Mo}$ ) are strongly influenced by the compositions of solutions enriched in calcium. Boron may precipitate to form calcium borate. In low $\mathrm{pH}$ solution (S5), the initial dissolution rate is decreased by a factor of $\sim 18$, suggesting that $\mathrm{Si}$ enrichment in solution, released by silica fume from low-pH HCP, controls the dissolution of ILW glass.

A mechanism of diffusion type has been identified over the whole duration of the experiments (850 days). The study of lowpH HCP dissolution in contact with glass gives promising results in terms of dissolution rates and the chemical durability of glass. Monolith glass alteration in the absence/presence of HCP and glass powder shows the formation of an altered surface layer, mainly constituted of calcium silicate hydrates with low $\mathrm{Ca} / \mathrm{Si}$ ratios. These phases consume aqueous silica and thus sustain glass dissolution.

Finally, in the context of ILW glass disposal in a cement environment, developing low-pH cements as an alternative to high-pH cements could be a promising alternative. Nevertheless, long-term dissolution experiments and a thorough characterization of the alteration products are required for the understanding and modelling of long-term glass dissolution.

\section{Conflicts of interest}

There are no conflicts to declare.

\section{Acknowledgements}

The authors acknowledge Andra for the financial support, and CEA and Orano Cycle for supplying ILW glass samples. We would like to express our sincere gratitude to Véronique Baty (Subatech laboratory) for ion chromatography analyses, Damien Salou (Subatech laboratory) for performing batch experiments, and Nicolas Stephant (Institut des Matériaux - Jean Rouxel de Nantes, IMN) for SEM/EDX analyses.

\section{References}

1 ASN, in Les activités contrôlées par l'ASN, 2010.

2 ANDRA, Dossier 2005: Référentiel des matériaux d'un stockage de déchets à haute activité et à vie longue, 2005.

3 E. Y. Vernaz and N. Godon, MRS Online Proc. Libr., 1991, 257, 37.

4 S. Gin, N. Godon, I. Ribet, P. Jollivet, Y. Minet, P. Frugier, E. Vernaz, J. M. Cavedon, B. Bonin and R. D. Quang, Mater. Res. Soc. Symp. Proc., 2004, 824, 327-332.

5 S. Gin, P. Jollivet, J. P. Mestre, M. Jullien and C. Pozo, Appl. Geochem., 2001, 16, 861-881.

6 S. Gin and J. P. Mestre, J. Nucl. Mater., 2001, 295, 83-96.

7 T. Advocat, P. Jollivet, J. L. Crovisier and M. Del Nero, J. Nucl. Mater., 2001, 298, 55-62.

8 S. Peuget, J.-N. Cachia, C. Jegou, X. Deschanels, D. Roudil, V. Broudic, J. M. Delaye and J.-M. Bart, J. Nucl. Mater., 2006, 354, 1-13.

9 E. Vernaz, S. Gin, C. Jegou and I. Ribet, J. Nucl. Mater., 2001, 298, 27-36.

10 F. Delage, D. Ghaleb, J. L. Dussossoy, O. Chevallier and E. Vernaz, J. Nucl. Mater., 1992, 190, 191-197.

11 P. Frugier, S. Gin, J. E. Lartigue and E. Deloule, Mat. Res. Soc. Symp. Proc., 2006, 932, 305-312.

12 P. Frugier, T. Chave, S. Gin and J. E. Lartigue, J. Nucl. Mater., 2009, 392, 552-567.

13 B. Grambow, Mater. Res. Soc. Symp. Proc., 1985, 44, 15-27.

14 B. Grambow and R. Müller, J. Nucl. Mater., 2001, 298, 112124.

15 P. Frugier, S. Gin, Y. Minet, T. Chave, B. Bonin, N. Godon, J. E. Lartigue, P. Jollivet, A. Ayral, L. De Windt and G. Santarini, J. Nucl. Mater., 2008, 380, 8-21.

16 S. Gin, I. Ribet and M. Couillard, J. Nucl. Mater., 2001, 298, 110. 
17 E. Y. Vernaz and J. L. Dussossoy, Appl. Geochem., 1992, 7, 1322.

18 T. Geisler, A. Janssen, D. Scheiter, T. Stephan, J. Berndt and A. Putnis, J. Non-Cryst. Solids, 2010, 356, 1458-1465.

19 R. Hellmann, S. Cotte, E. Cadel, S. Malladi, L. S. Karlsson, S. Lozano-Perez, M. Cabié and A. Seyeux, Nat. Mater., 2015, 14, 307.

20 Ministère De L'écologie/De L'énergie/Du Développement Durable Et De La Mer, J. Off. la République Française, Décret no 2009-961 du 31 juillet 2009.

21 AREVA, AREVA - BG AVAL, Dir. Matières Déchets Radioact. NOTE Tech. DMDR NT 15-0010.

22 IRSN, Avis de l'IRSN relative à la spécification référencée $300-$ AQ-061 pour le conditionnement par vitrification d'effluents de moyenne activité, 2009.

23 ANDRA, Catalogue descriptif des familles, 2015.

24 ANDRA, Référentiel des matériaux d'un stockage de déchets de haute activité et de déchets de moyenne activité et à vie longue, Tome 2: les matériaux cimentaires, 2012.

25 ANDRA, Sites en exploitation: La Hague, Basse Normandie, 2016.

26 A. Ait Chaou, A. Abdelouas, Y. El Mendili, R. Bouakkaz, S. Utsunomiya, C. Martin and X. Bourbon, R. Soc. Chem. Adv., 2015, 5, 64538-64549.

27 S. Depierre, Etude Des Mécanismes d'altération Du Verre Par Des Eaux Cimentaires, Université de Montpellier II, France, 2012.

28 S. Mercado-Depierre, F. Angeli, F. Frizon and S. Gin, J. Nucl. Mater., 2013, 441, 402-410.

29 D. G. Bennett and R. Gens, J. Nucl. Mater., 2008, 379, 1-8.

30 P. A. Bingham, N. C. Hyatt and R. J. Hand, Glass Technol.: Eur. J. Glass Sci. Technol., Part A, 2012, 53, 83-100.

31 C. A. Utton, R. J. Hand, P. A. Bingham, N. C. Hyatt, S. W. Swanton and S. J. Williams, J. Nucl. Mater., 2013, 435, 112-122.

32 S. M. Wickham, M. B. Crawford and D. G. Bennett, Eval. Ref. Des. Galson Sci. LTD, Oakham, 2005.

33 T. Chave, P. Frugier, S. Gin and A. Ayral, Geochim. Cosmochim. Acta, 2011, 75, 4125-4139.

34 P. Jollivet, P. Frugier, G. Parisot, J. P. Mestre, E. Brackx, S. Gin and S. Schumacher, J. Nucl. Mater., 2012, 420, 508-518.

35 G. J. Stockmann, D. Wolff-Boenisch, S. R. Gislason and E. H. Oelkers, Chem. Geol., 2011, 284, 306-316.

36 C. Cau Dit Coumes, S. Courtois, D. Nectoux, S. Leclercq and X. Bourbon, Cem. Concr. Res., 2006, 36, 2152-2163.

37 D. Rothstein, J. J. Thomas, B. J. Christensen and H. M. Jennings, Cem. Concr. Res., 2002, 32, 1663-1671.

38 K. De Weerdt, M. Ben Haha, G. Le Saout, K. O. Kjellsen, H. Justnes and B. Lothenbach, Cem. Concr. Res., 2011, 41, 279-291.

39 B. Lothenbach, G. Le Saout, E. Gallucci and K. Scrivener, Cem. Concr. Res., 2008, 38, 848-860.

40 B. Lothenbach, T. Matschei, G. Möschner and F. P. Glasser, Cem. Concr. Res., 2008, 38, 1-18.

41 M. C. Alonso, L. Fernandez-Luco, J. L. Garcia, A. Hidalgo and F. Huertas, in Proceedings of the 12th International Congress on the Chemistry of Cement, Montreal, Canada, Citeseer, 2007, pp. 8-13.

42 A. Dauzères, P. Le Bescop, C. Cau-Dit-Coumes, F. Brunet, X. Bourbon, J. Timonen, M. Voutilainen, L. Chomat and P. Sardini, Cem. Concr. Res., 2014, 58, 76-88.

43 A. Jenni, U. Mäder, C. Lerouge, S. Gaboreau and B. Schwyn, Physics and Chemistry of the Earth, Parts A/B/C, 2014, 70, 7183.

44 A. Dauzères, G. Achiedo, D. Nied, E. Bernard, S. Alahrache and B. Lothenbach, Cem. Concr. Res., 2016, 79, 137-150.

45 K. Ferrand, S. Liu and K. Lemmens, Procedia Mater. Sci., 2014, 7, 223-229.

46 M. Codina, Les Bétons Bas PH. Formulation, Caractérisation et Étude à Long Terme, Institut National des Sciences Appliquées, Toulouse, France, 2007.

47 D. L. Parkhurst and C. A. J. Appelo, User's guide to Phreeqc (version 2) _ A computer program for speciation, batch reaction, one-dimensional transport, and inverse geochemical calculations, Water-resources investigations Report, Denver, CO USA, 1999.

48 L. Duro, M. Grivé and E. Giffaut, in MRS Proceedings, Cambridge Univ Press, 2012, vol. 1475, pp. imrc11-1475nw35-o71.

49 L. Trotignon, H. Peycelon and X. Bourbon, Procedia Mater. Sci., 2006, 31, 610-617.

50 V. Gabis, Bull. Soc. Fr. Mineral. Cristallogr., 1958, 81, 183185.

51 D. Guimaraes, V. de A. Oliveira and V. A. Leao, J. Therm. Anal. Calorim., 2016, 124, 1679-1689.

52 R. B. Perkins and C. D. Palmer, Geochim. Cosmochim. Acta, 1999, 63, 1969-1980.

53 B. A. Clark and P. W. Brown, Cem. Concr. Res., 2000, 30, 233240.

54 D. Damidot and F. P. Glasser, Cem. Concr. Res., 1992, 22, 1179-1191.

55 M. Fournier, P. Frugier and S. p Gin, Procedia Mater. Sci., 2014, 7, 202-208.

56 R. J. Kirkpatrick, J. L. Yarger, P. F. McMillan, Y. Ping and X. Cong, Adv. Cem. Based Mater., 1997, 5, 93-99.

57 G. Renaudin, R. Segni, D. Mentel, J.-M. Nedelec, F. Leroux and C. Taviot-Gueho, J. Adv. Concr. Technol., 2007, 5, 299312.

58 J. Dweck, P. F. Ferreira da Silva, P. M. Büchler and F. K. Cartledge, J. Therm. Anal. Calorim., 2002, 69, 179-186.

59 J. Dweck, P. M. Buchler, A. C. V. Coelho and F. K. Cartledge, Thermochim. Acta, 2000, 346, 105-113.

60 K. Matsui, J. Kikuma, M. Tsunashima, T. Ishikawa, S. Matsuno, A. Ogawa and M. Sato, Cem. Concr. Res., 2011, 41, 510-519.

61 T. Sugama, L. E. Kukacka and W. Horn, J. Mater. Sci., 1981, 16, 345-354.

62 ANDRA, Référentiel des matériaux d'un stockage de déchets de haute activité et de déchets de moyenne activité et à vie longue, Tome 2: les matériaux cimentaires, 2012.

63 B. Grambow, in Uhlig's Corrosion Handbook: Third Edition, 2011. 